Article

\title{
Production of Liquid Milk Protein Concentrate with Antioxidant Capacity, Angiotensin Converting Enzyme Inhibitory Activity, Antibacterial Activity, and Hypoallergenic Property by Membrane Filtration and Enzymatic Modification of Proteins
}

\author{
Arijit Nath ${ }^{1, *}$, Burak Atilla Eren ${ }^{1}\left(\mathbb{0}\right.$, Attila Csighy ${ }^{1}$, Klára Pásztorné-Huszár ${ }^{2}$, Gabriella Kiskó ${ }^{3}$, \\ László Abrankó ${ }^{4}$, Attila Tóth ${ }^{5}$, Emóke Szerdahelyi ${ }^{6}$, Zoltán Kovács ${ }^{7} \mathbb{D}$, András Koris ${ }^{1}$ and \\ Gyula Vatai ${ }^{1, *}$ \\ 1 Department of Food Engineering, Faculty of Food Science, Szent István University, Ménesi st 44, \\ HU-1118 Budapest, Hungary; Eren.Burak.Atilla@hallgato.uni-szie.hu (B.A.E.); \\ Attila.Csighy@phd.uni-szie.hu (A.C.); Koris.Andras@etk.szie.hu (A.K.) \\ 2 Department of Refrigeration and Livestock Products Technology, Faculty of Food Science, \\ Szent István University, Ménesi út 43-45, HU-1118 Budapest, Hungary; pasztorne.huszar.klara@etk.szie.hu \\ 3 Department of Food Microbiology and Biotechnology, Faculty of Food Science, Szent István University, \\ Somlói st 14-16, HU-1118 Budapest, Hungary; Kisko.Gabriella@etk.szie.hu \\ 4 Department of Applied Chemistry, Faculty of Food Science, Szent István University, Villányi út 29-43, \\ HU-1118 Budapest, Hungary; Abranko.Laszlo@etk.szie.hu \\ 5 Division of Clinical Physiology, Department of Cardiology, Faculty of Medicine, University of Debrecen, \\ Móricz Zsigmond Str 22, HU-4032 Debrecen, Hungary; atitoth@med.unideb.hu \\ 6 Department of Biology, National Agricultural Research and Innovation Center, Food Science Research \\ Institute, Herman Ottó út 15, HU-1022 Budapest, Hungary; szerdahelyi.emoke@eki.naik.hu \\ 7 Department of Physics and Control, Faculty of Food Science, Szent István University, Somlói street 14-16, \\ HU-1118 Budapest, Hungary; Kovacs.Zoltan3@etk.szie.hu \\ * Correspondence: arijit0410@gmail.com (A.N.); Vatai.Gyula@etk.szie.hu (G.V.); \\ Tel.: +36-1-305-7110 (A.N.); +36-1-305-7115 (G.V.)
}

Received: 3 June 2020; Accepted: 10 July 2020; Published: 18 July 2020

\begin{abstract}
Liquid milk protein concentrate with different beneficial values was prepared by membrane filtration and enzymatic modification of proteins in a sequential way. In the first step, milk protein concentrate was produced from ultra-heat-treated skimmed milk by removing milk serum as permeate. A tubular ceramic-made membrane with filtration area $5 \times 10^{-3} \mathrm{~m}^{2}$ and pore size $5 \mathrm{~nm}$, placed in a cross-flow membrane house, was adopted. Superior operational strategy in filtration process was herein: trans-membrane pressure 3 bar, retention flow rate $100 \mathrm{~L} \cdot \mathrm{h}^{-1}$, and implementation of a static turbulence promoter within the tubular membrane. Milk with concentrated proteins from retentate side was treated with the different concentrations of trypsin, ranging from $0.008-0.064 \mathrm{~g} \cdot \mathrm{L}^{-1}$ in individual batch-mode operations at temperature $40^{\circ} \mathrm{C}$ for $10 \mathrm{~min}$. Subsequently, inactivation of trypsin in reaction was done at a temperature of $70^{\circ} \mathrm{C}$ for $30 \mathrm{~min}$ of incubation. Antioxidant capacity in enzyme-treated liquid milk protein concentrate was measured with the Ferric reducing ability of plasma assay. The reduction of angiotensin converting enzyme activity by enzyme-treated liquid milk protein concentrate was measured with substrate (Abz-FRK(Dnp)-P) and recombinant angiotensin converting enzyme. The antibacterial activity of enzyme-treated liquid milk protein concentrate towards Bacillus cereus and Staphylococcus aureus was tested. Antioxidant capacity, anti-angiotensin converting enzyme activity, and antibacterial activity were increased with the increase of trypsin concentration in proteolytic reaction. Immune-reactive proteins in enzyme-treated liquid milk protein concentrate were identified with clinically proved milk positive pooled human serum and
\end{abstract}


peroxidase-labelled anti-human Immunoglobulin E. The reduction of allergenicity in milk protein concentrate was enzyme dose-dependent.

Keywords: liquid milk protein concentrate; antioxidant capacity; angiotensin converting enzyme inhibitory activity; antibacterial activity; hypoallergenic property

\section{Introduction}

For years, different types of non-fermented and fermented dairy-based food formulas are received great attention among different communities. As time progressed, dairy industries tried their best to improve the quality of dairy-based formulas to fulfill the expectations of consumers [1]. For industrial production of fermented dairy products, milk with a standardized amount of protein is necessary to maintain the quality of products [2,3]. Different dairy-based protein concentrates, such as milk protein concentrate, milk protein isolate, whey protein concentrate, whey protein isolate, micellar casein concentrate, micellar casein isolate, whey concentrate, and selectively demineralized whey concentrate are widely used in the food and biopharmaceutical industries [4]. Milk protein concentrate is well accepted among all communities because it is an abundant source of the various kinds of proteins, including micellar casein, whey proteins, and glycomacropeptide, and has significantly lower amounts of lactose and fat compared to whey protein concentrate and whole milk protein concentrate, respectively [5]. Therefore, it is popularly used to prepare infant formula, protein bar, yogurt, recombined cheese, cultured product, frozen dessert, weight management products, and sports formulas [6]. To produce dairy-based protein concentrate, large-scale production plants with different unit operations are requirement. It may be noted that production of milk varies throughout the year. During the spring season, milk production is quite high compared to the fall season. To balance economic competitiveness, small-scale and medium-scale dairy industries avoid expensive processing steps, such as evaporation and drying to prepare dairy-based protein concentrate in powder form, and prefer to use liquid milk protein concentrate for manufacturing fresh cultured-food products $[7,8]$.

In the dairy industry, application of membrane technology is noteworthy. Membrane technology is used for preparing concentrated milk proteins, fractionation of dairy proteins, demineralization of whey, and removal of microbial count in milk [9-11]. In some cases, ultrafiltration or nanofiltration operated with diafiltration mode was adopted to achieve high protein concentrate and avoid membrane fouling [12-14]. Some limitations in this context are reported. The limitations are (a) development of gel layer (concentration polarization) on the membrane surface and subsequent membrane fouling, and (b) high energy consumption. During filtration, due to deposition of solute molecules on the membrane surface, concentration polarization take place on the membrane surface. Because of this, permeate flux is reduced in drastic way [15-17]. However, increase of trans-membrane pressure (TMP) or fluid flow through a mechanical pump reduces the development of gel layer on the membrane surface; there is a debating issue about high energy consumption [18,19]. Therefore, it may feel that an efficient membrane separation process and its operational strategy are needed to explore to produce liquid milk protein concentrate.

However, milk has gained a great attention around the globe due to the presence of the different types of proteins ( $\alpha_{\mathrm{S} 1}$-casein, $\alpha_{\mathrm{S} 2}$-casein, $\beta$-casein, $\mathrm{k}$-casein, $\gamma$-casein, immunoglobulin, bovine serum albumin, lactoferrin, $\alpha$-lactalbumin, and $\beta$-lactoglobulin), lactose, vitamins (vitamin $A$, vitamin $E$, ascorbic acid, riboflavin, vitamin B6, nicotinic acid, pantothenic acid, and thiamin) and minerals (calcium, magnesium, phosphorus, potassium, selenium, and zinc) [20]. The milk sensitive community frequently experiences with the symptoms of immunoglobulin-mediated milk protein allergies, in some cases [21,22]. Due to the presence of Immunoglobulin E- and Immunoglobulin G- binding epitopes, milk proteins are listed among the "big 8 " allergens [23,24]. Milk allergens provoke mild symptoms to life-threatening biochemical outcomes, including severe enterocolitis atopic eczema and immediate 
immunoglobulin-mediated systematic multisystem reactions [25]. Milk is not recommended in the diet chart due to the presence of saturated fatty acids-those contribute heart disease [26,27], type 2 diabetes, and Alzheimer's disease [28,29]. Furthermore, due to the absence of lactase, a hydrolytic enzyme in brush border of epithelial cells in the small intestine, the milk sensitive community frequently suffers with symptoms of lactose maldigestion [20,21]. However, concentrations of lactose and fat in milk protein concentrate are significantly low; in some cases, food formulas fortified with milk protein concentrate offer immunoglobulin-mediated allergies among people of all ages [30,31]. A plethora of literature about thermal and non-thermal processing technologies have been adopted to combat milk protein allergens [32,33]. The reduction in protein allergenicity in the molecular basis is the destruction of structure of epitopes. Applications of high pressure- [34,35], heat- [36-38], microwave- [39], and membrane bioreactors [40,41] were implemented for the reduction of allergenic sequences in milk proteins. In some cases, physical- [42-44] and enzymatic- [45-48] modifications of proteins have been adopted for a similar objective. Furthermore, combined physical and biochemical technologies have been adopted for the reduction of milk protein allergens [49-56]. In some cases, new epitopes (neoepitopes) or hidden epitopes may even be produced during cow milk processing due to denaturation of native allergen (cryptotopes) [57]. Realizing advantages and disadvantages of mentioned technologies, it may feel that enzymatic hydrolysis of allergenic epitopes in protein sequences may be an effective attempt to reduce milk protein allergens. Besides the elimination of their allergenic potentiality, modification of milk proteins through enzymatic routes may alter their functional properties, because peptides with unique amino acids in $\mathrm{C}$ - and $\mathrm{N}$ - terminal positions are produced through enzymatic hydrolysis of peptide bonds in milk proteins. Furthermore, the enzymatic modification of milk proteins may generate new antigenic substances, which may offer immunomodulation, and provide extra health benefits [58]. However, lots of information about the reduction of allergenic epitopes in milk proteins through an enzymatic route are stored in scholarly databases; its production in industrial scale is limited [59]. The challenging issues in enzyme-mediated process are (a) high cost of enzymes, and (b) find out suitable operating process parameters in enzyme-mediated processes. Therefore, it can feel that an investigation is needed to find out the minimum amount of enzymes, which is responsible for reducing a significant amount $(>99.9 \%)$ of the allergenic sequence and improve the functional activities of milk protein concentrate. Trypsin is an endopeptidase generally found in the pancreas of mammalians, and cleaves at the carboxyl terminal side of arginine and lysine amino acid residues, except arginyl-proline and lysyl-proline bonds. It is popularly used for preparation of dairy formulations with lower antigenic activities $[60,61]$. As the catalytic activity of trypsin is quite high (relative activity $99 \%$ ) at $\mathrm{pH} 7$ and may be able to change the biological activity of proteins and peptides [62-64], it was used in this investigation.

From the above discussion, one can realize that efforts are needed to reduce the limitations of milk protein concentrate production and dairy product consumption. In this investigation, an attempt was considered to develop liquid milk protein concentrate from ultra-heat-treated skimmed milk with antioxidant capacity, angiotensin converting enzyme inhibitory activity, antibacterial activity, and hypoallergenic property by membrane filtration and enzymatic modification of proteins in a sequential way. In the present investigation, membrane filtration process was adopted to increase the protein concentration in milk by reducing the milk serum as permeate and, subsequently, trypsin was adopted to hydrolyze the concentrated liquid milk proteins, obtained at the retentate side. Membrane filtration process itself cannot change the structural and biological activities of milk proteins. Peptides, produced by enzymatic hydrolysis of milk proteins with unique $\mathrm{C}$ - and $\mathrm{N}$-terminal amino acids, peptide length, and amino acid sequence, offer distinguishing biological activities. Furthermore, allergenic activity of proteins is reduced due to enzymatic cleavage in allergenic epitopes within the amino acid sequence in protein. 


\section{Materials and Methods}

\subsection{Chemicals and Reagents}

Lyophilized trypsin ( $\geq 27.78$ units per $\mathrm{mg}$ of solid at temperature $25^{\circ} \mathrm{C}$ ) from bovine pancreas, Bradford reagent, bovine serum albumin, casein, $\alpha$-lactalbumin and $\beta$-lactoglobulin from bovine milk, Abz-FRK(Dnp)-P, peroxidase-labelled anti-human Immunoglobulin E, 2,4,6-Tris(2-pyridyl)-s-triazine $(\geq 98 \%)$, 4-chloronaphtol $(\geq 98 \%)$, hydrogen peroxide $(\geq 98 \%)$, ethanol $(\geq 99 \%)$, and phosphate buffered saline solution were purchased from the Sigma-Aldrich (Sigma-Aldrich, Schnelldorf, Germany). Ultrasil P3-11 was purchased from Ecolab-Hygiene Kft (Ecolab-Hygiene Kft, Budapest, Hungary). Citric acid (99\%), hydrochloric acid ( $\geq 99 \%)$, urea ( $\geq 99 \%)$, dithiothreitol (DTT) and sodium hydroxide $(\geq 99 \%)$ were purchased from Reanal Kft (Reanal Kft, Budapest, Hungary). Ferric chloride $(\geq 99 \%$ ), sodium acetate (anhydrous, $\geq 99 \%$ ), sodium chloride $(\geq 99 \%)$, zinc chloride $(\geq 99 \%)$, bacteriological agar powder, soybean casein digestive medium and ascorbic acid (99.7\%) were procured from Merck (Merck, Darmstadt, Germany). Sodium-dodecyl sulphate ( $\geq 99 \%)$, acrylamide $(\geq 99 \%)$, ammonium persulfate $(\geq 99 \%)$, bis-acrylamide $(\geq 99 \%)$, tetramethylethylenediamine $(\geq 99 \%)$, tris(hydroxymethyl)aminomethane hydrochloride (TRIS HCl), ethyl alcohol ( $\geq 99 \%$ ), glycine $(\geq 99 \%)$, coomassie blue stain R250 ( $\geq 99 \%)$, acetic acid ( $\geq 99 \%)$, glycerol ( $\geq 99 \%)$, isopropanol ( $\geq 99 \%)$, $2 \beta$-mercaptoethanol ( $\geq 99 \%$ ), and bromophenol blue ( $\geq 99 \%)$ were procured from Bio-Rad (Bio-Rad, Hercules, USA). High performance liquid chromatography mass spectrometry (HPLC-MS)-grade acetonitrile, formic acid, and trisodium citrate ( $\geq 99 \%)$ were purchased from VWR International Ltd. (VWR International Ltd., Debrecen, Hungary). Recombinant angiotensin converting enzyme was kindly provided by Division of Clinical Physiology, Institute of Cardiology, University of Debrecen (University of Debrecen, Debrecen, Hungary). Bacillus cereus and Staphylococcus aureus ATCC 6538 were collected from the Strain collection unit of Szent István University (Szent István University, Budapest, Hungary). Milli-Q ultrapure deionized water $(18.2 \mathrm{M} \Omega \cdot \mathrm{cm})$ was obtained from Milli-Q Synergy/Elix water purification system (Merck-Millipore, Molsheim, France) and used throughout the experiment.

\subsection{Ultra-Heat-Treated Skimmed Cow Milk}

Ultra-heat-treated skimmed cow milk was procured from local supermarkets, in and around Budapest, Hungary. Concentrations of protein, lactose, and fat in milk were in average $31 \pm 0.16 \mathrm{~g} \cdot \mathrm{L}^{-1}$, $47 \pm 0.15 \mathrm{~g} \cdot \mathrm{L}^{-1}$ and $1 \pm 0.02 \mathrm{~g} \cdot \mathrm{L}^{-1}$, respectively. Average $\mathrm{pH}$ of milk was 6.8 . Milk was stored in a refrigerator at temperature $10^{\circ} \mathrm{C}$.

\subsection{Production of Hypoallergenic Liquid Milk Protein Concentrate with Functional Values}

An attempt was considered to develop a process to produce allergen-free liquid milk protein concentrate with functional values, such as antioxidant capacity, angiotensin converting enzyme inhibitory activity, and antibacterial activity. Combination of different physical- and biochemicalbased technologies were adopted for this purpose (Figure 1). 


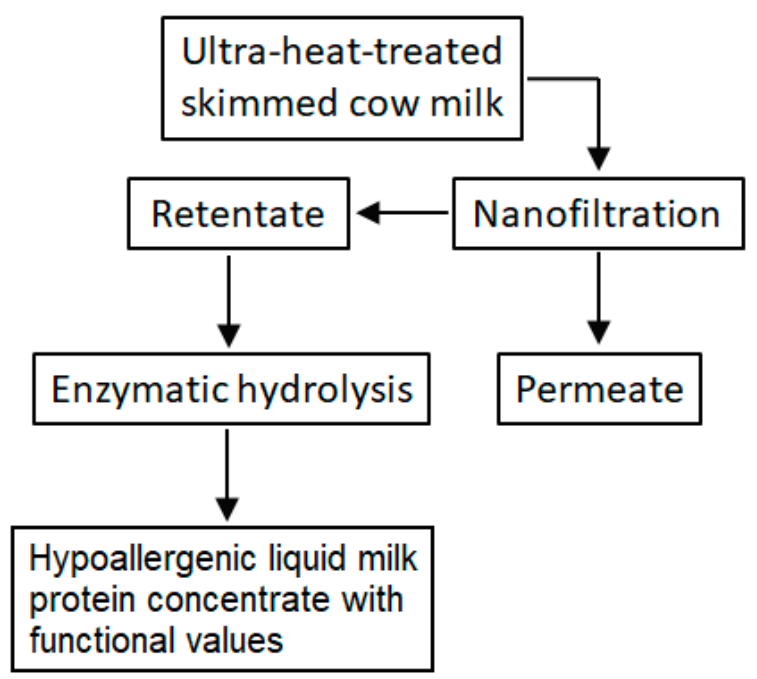

Figure 1. Experimental steps for preparing hypoallergenic liquid milk protein concentrate with functional values (antioxidant capacity, angiotensin converting enzyme inhibitory activity, and antibacterial activity).

\subsubsection{Concentrate Milk Proteins in Ultra-Heat-Treated Skimmed Milk by Membrane Technology}

De-watering (remove of milk serum) of ultra-heat-treated skimmed milk was performed by a tubular nanofiltration membrane with active filtration area $5 \times 10^{-3} \mathrm{~m}^{2}$ and pore size $5 \mathrm{~nm}$ (Pall Corporation, Crailsheim, Germany), placed in a stainless steel-made cross-flow membrane module (Figure 2). The active layer, support layer, length, inner diameter, and outer diameter of the membrane were titanium oxide, aluminum oxide, $250 \mathrm{~mm}, 7 \mathrm{~mm}$, and $10 \mathrm{~mm}$, respectively. In the membrane module, feed flow rate was controlled by a centrifugal pump (Verder Hungary Kft, Budapest, Hungary). Flow rate of fluid (milk, water) in the membrane module was also controlled by a rotameter at a retentate flow channel and a bypass channel at the inlet channel of the membrane module. TMP of the membrane module was controlled by pressure gauges, fitted at inlet and retentate flow channels of the membrane module. A mechanical agitator was fitted inside of the storage tank of the membrane module. Temperature in the storage tank of the membrane module was maintained by a temperature sensor and automated circulation of warm/cold water within the water jacket.

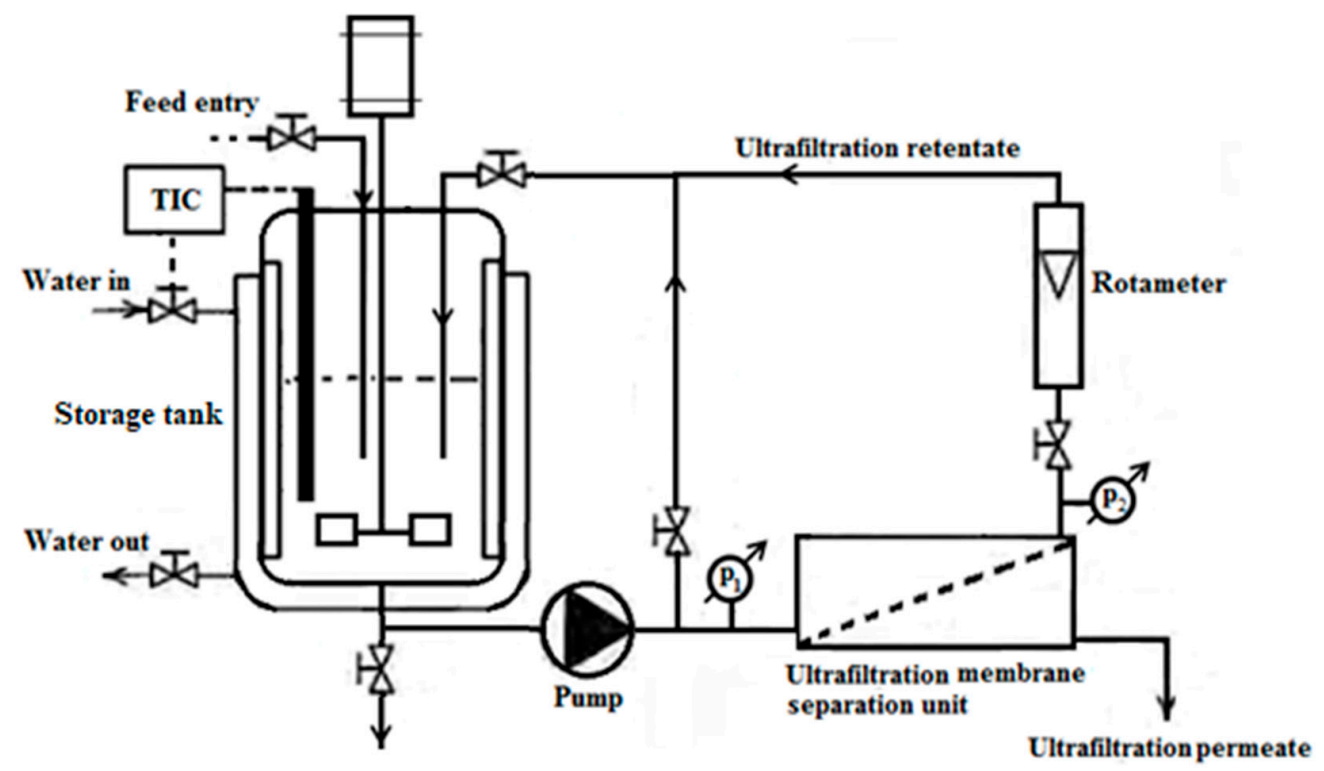

Figure 2. Schematic diagram of the cross-flow membrane module. 
A mechanical device, known as static turbulence promoter, made of stainless steel (SS316), was inserted within the membrane tube. Detailed geometry of the static turbulence promoter is mentioned in an earlier publication [65]. To investigate the effects of process parameters in filtration process, different TMPs, such as 2 bar and 3 bar, and retention flow rates (RFRs), such as $100 \mathrm{~L} \cdot \mathrm{h}^{-1}$ and $200 \mathrm{~L} \cdot \mathrm{h}^{-1}$, were used with or without the static turbulence promoter. Each membrane filtration experiment started with $1 \mathrm{~L}$ of ultra-heat-treated skimmed milk, and volume reduction factor 2 was considered. Membrane filtration process was performed with a batch recirculation mode. Constant volume of permeate from the membrane was collected at different time fractions and permeate flux $(J)$ was calculated with the following equation.

$$
J=V /(A \times t)
$$

where, $J=$ permeate flux during filtration $\left(\mathrm{L} \mathrm{m}^{-2} \cdot \mathrm{h}^{-1}\right), V=$ volume of permeate $(\mathrm{L}), A=$ active membrane filtration area $\left(\mathrm{m}^{2}\right)$ and $t=$ filtration time (h) [66].

In the feed tank, after $50 \%$ reduction of volume (volume reduction factor 2), reduction of permeate flux $(\Delta J)$ was calculated from initial permeate flux with Equation (2).

$$
\Delta J(\%)=\left(J_{\text {initial }}-J_{\text {final }}\right) \times 100 / J_{\text {initial }}
$$

where, $\Delta J=$ reduction of permeate flux $(-), J_{\text {initial }}=$ initial permeate flux $\left(\mathrm{L} \mathrm{m}^{-2} \cdot \mathrm{h}^{-1}\right)$ and $J_{\text {final }}=$ final permeate flux $\left(\mathrm{L} \mathrm{m}^{-2} \cdot \mathrm{h}^{-1}\right)$ [65].

During filtration, pressures at inlet and retentate flow channels of the membrane module were recorded. Specific energy consumption $\left(E_{s}\right)$ was calculated with Equation (3).

$$
E_{\mathrm{s}}=(R F R \times \Delta p) /\left(\text { initial }_{\text {in }} \times A\right)
$$

where, $E_{S}=$ specific energy consumption $\left(\mathrm{kWh} \cdot \mathrm{m}^{-3}\right), Q_{\mathrm{R}}=$ retention flow rate $\left(\mathrm{L} \cdot \mathrm{h}^{-1}\right), \Delta p=$ difference of pressure $\left(\right.$ Newton $\left.\cdot \mathrm{m}^{-2}\right), A=$ active membrane filtration area $\left(\mathrm{m}^{2}\right)$ and $J_{\text {initial }}=$ initial permeate flux $\left(\mathrm{L} \mathrm{m}^{-2} \cdot \mathrm{h}^{-1}\right)$ [65].

After removing the milk serum, membrane cleaning was performed with $1 \%$ ultrasil and $1 \%$ citric acid in a sequential way with intermediate water cleaning. During cleaning with ultrasil and citric acid, TMP 0.8 bar and RFR $200 \mathrm{~L} \mathrm{~h}^{-1}$ were used. During cleaning with water, TMP 4 bar and RFR $200 \mathrm{~L} \mathrm{~h}^{-1}$ were used. Prior to removing the milk serum, membrane compaction was performed with de-ionized water to achieve the steady state water permeate flux. For that purpose, TMP 4 bar and RFR $200 \mathrm{~L} \cdot \mathrm{h}^{-1}$ were used [67].

\subsubsection{Enzymatic Hydrolysis of Concentrated Proteins in Milk}

Milk with concentrated proteins was collected from the storage tank of the membrane module. Prior to enzymatic reaction, milk with concentrated proteins, $\mathrm{pH} 7$ was pre-incubated until the temperature reached $40^{\circ} \mathrm{C}$ in a laboratory-scale well-controlled jacketed bioreactor, working volume $0.6 \mathrm{~L}$ and aspect ratio H/D*2:1 (Solida Biotech, München, Germany). After pre-incubation of milk with concentrated proteins, it was treated with different concentrations of trypsin, such as $0.008 \mathrm{~g} \cdot \mathrm{L}^{-1}$, $0.016 \mathrm{~g} \cdot \mathrm{L}^{-1}, 0.032 \mathrm{~g} \cdot \mathrm{L}^{-1}$, and $0.064 \mathrm{~g} \cdot \mathrm{L}^{-1}$. Individual batch-mode experiments were performed for protein hydrolysis process. For that purpose, $450 \mu \mathrm{L}, 900 \mu \mathrm{L}, 1.8 \mathrm{~mL}$, and $3.6 \mathrm{~mL}$ of trypsin solution from stock solution (concentration of trypsin $0.009 \mathrm{~g} \cdot \mathrm{mL}^{-1}$ ) were injected through $0.22 \mu \mathrm{m}$ of polytetrafluoroethylene (PTFE) syringe filter (VWR International, Pennsylvania, USA) to $500 \mathrm{~mL}$ of milk with concentrated proteins in bioreactor [67]. Enzymatic reaction was performed at a temperature of $40^{\circ} \mathrm{C}$ for $10 \mathrm{~min}[68,69]$. During enzymatic reaction, agitation speed in the bioreactor was maintained, $175 \mathrm{rpm}$, and the $\mathrm{pH}$ of milk in the bioreactor was controlled, 6.8, by automated addition of $2.0 \mathrm{~N}$ of sodium hydroxide or hydrochloric acid [67]. After $10 \mathrm{~min}$ of enzymatic reaction, $20 \mathrm{~mL}$ of sample was collected by a syringe from the bioreactor and kept in a sample tube. Activity of 
trypsin in enzymatic reaction was stopped by heat treatment. For that purpose, sample tubes were immediately placed in a water bath at temperature $70^{\circ} \mathrm{C}$ for $30 \mathrm{~min}$ because denaturation temperatures of bovine $\alpha$-lactalbumin and $\beta$-lactoglobulin are $\sim 75^{\circ} \mathrm{C}$ [70-72]. Two control samples (without enzyme treatment) were considered in the experiment: control 1: ultra-heat-treated skimmed milk was heated at temperature $40{ }^{\circ} \mathrm{C}$ for $10 \mathrm{~min}$ and subsequently placed at temperature $70{ }^{\circ} \mathrm{C}$ for $30 \mathrm{~min}$; control 2: milk with concentrated protein was heated at temperature $40^{\circ} \mathrm{C}$ for $10 \mathrm{~min}$ and subsequently placed at temperature $70{ }^{\circ} \mathrm{C}$ for $30 \mathrm{~min}$. After inactivation of trypsin, the temperature of samples (reaction mixture) was reduced to ambient temperature $\left(\sim 25^{\circ} \mathrm{C}\right)$ and freshly prepared samples were used for all kinds of biochemical assay, described in Section 2.4 .

\subsection{Analytical Method}

\subsubsection{Understanding of Molecular Weight of Proteins in Concentrated Milk}

Molecular weight of proteins in concentrated milk was determined by liquid chromatographyelectrospray ionization time-of-flight mass spectrometry (LC-ESI-TOF-MS) (Agilent Technologies, Santa Clara, CA, USA). Sample preparation was performed according to the protocol, mentioned by Rauh et al., 2015 [73]. Briefly, $200 \mu \mathrm{L}$ of concentrated milk was treated with $20 \mu \mathrm{L}$ of $0.5 \mathrm{M} \mathrm{DTT}, 1 \mathrm{~mL}$ of $100 \mathrm{mM}$ trisodium citrate, and $6 \mathrm{M}$ urea at temperature $30^{\circ} \mathrm{C}$ for $1 \mathrm{~h}$ in a thermostat. Subsequently, a sample was centrifuged at $9500 \mathrm{~g}$ for $20 \mathrm{~min}$ at temperature $4{ }^{\circ} \mathrm{C}$ by a laboratory centrifuge (HERMLE Labortechnik, Wehingen, Germany). Aliquot of the clear phase was collected aseptically and used for LC-MS analysis. Chromatographic separation was achieved by an XBridge BEH300 C4 column with particle size: $3.5 \mu \mathrm{m}$, and inner diameter x length: $2.1 \mathrm{~mm} \times 150 \mathrm{~mm}$ (Waters, Milford, USA), placed in an Agilent 1200 HPLC system (Agilent Technologies, Santa Clara, CA, USA). The column temperature was $30^{\circ} \mathrm{C}$ during chromatographic separation. The binary mobile phase consisted of Milli-Q ultrapure deionized water with $0.1 \%$ formic acid (eluent A), and acetonitrile (eluent B) was used for that purpose. The flow rate was set to $0.5 \mathrm{~mL} \cdot \mathrm{min}^{-1}$. Gradient separation started at 3\% B and linearly increased to reach $90 \%$ in 9 min. The eluent was kept constant at $90 \%$ B until 11 min and then the column was re-equilibrated at the initial conditions for $8 \mathrm{~min}$. A UV signal was recorded at $280 \mathrm{~nm}$ using the diode-array detector (DAD) in the LC system and the effluent was connected to an Agilent 6530 high-resolution, accurate-mass, quadrupole time-of-flight mass spectrometry system equipped with a dual sprayer electrospray ion source. The mass spectrometry was run with full scan, MS-only mode ( $2 \mathrm{GHz}$, extended dynamic range setup) scanning in the range of 50-3200 m/z in positive ionization mode. A continuous reference mass correction was applied using purine and HP-921 (Hexakis $(1 \mathrm{H}, 1 \mathrm{H}, 3 \mathrm{H}$-perfluoropropoxy)phosphazene) as reference substances. The ion source temperature was maintained at $325^{\circ} \mathrm{C}$, and capillary and fragmentor voltages were set to $-4000 \mathrm{~V}$ and $140 \mathrm{~V}$, respectively. The Mass Hunter (MH) Workstation software package (version B02.01) and MH BioConfirm (version B 09.00) (Agilent Technologies, Santa Clara, CA, USA) were used for data acquisition and data evaluation, respectively. For raw mass spectrum deconvolution, the maximum entropy algorithm was used with automatic mass range detection (for intact protein), and for multiply charged ions, 500-3000 m/z limited range was considered.

\subsubsection{Understanding of Hydrolysis of Liquid Milk Protein Concentrate}

Molecular weight of proteins in ultra-heat-treated skimmed milk, milk with concentrated proteins, and enzyme-treated milks was determined by the sodium dodecyl sulfate polyacrylamide gel electrophoresis (SDS-PAGE) method. For this purpose, a vertical electrophoresis system (Bio-Rad Mini Protean Tetra system) and standard protein marker (precision plus protein standards) from Bio-Rad (Bio-Rad, Hercules, CA, USA) were used. In the SDS-PAGE method, concentration of stacking gel and running gel were $6 \%$ and $15 \%$, respectively. The Laemmli sample buffer with 2-mercaptoethanol was used for dilution of samples and $10 \mu \mathrm{L}$ of appropriate diluted sample was loaded into the respective wells. $0.2 \%$ Coomassie Brillant Blue R250 was used for gel staining. After 30 min of gel staining, 
de-staining of gel was performed with $50 \%$ (volume basis) of methanol-water and $10 \%$ (volume basis) of acetic acid. Gel image was captured using a Gel Doc XR+ System (Bio-Rad, Hercules, USA) and the molecular weight of bands were determined using Quantity One software program (version 4.6) (Bio-Rad, Hercules, CA, USA) [74].

\subsubsection{Immunoblotting of Concentrated Milk Proteins}

Proteins from SDS-PAGE gel were transferred onto a $0.45 \mu \mathrm{m}$ of polyvinylidene difluoride (PVDF) membrane (Merck-Millipore, Molsheim, France) by a trans blot semi-dry transfer cell (Bio-Rad, Hercules, CA, USA). It was operated with $0.25 \mathrm{~V}$ and $0.08 \mathrm{~mA} / \mathrm{cm}^{2}$ for $60 \mathrm{~min}$. Immune-reactive proteins were identified with clinically proved milk positive pooled human serum and peroxidase-labelled anti-human Immunoglobulin E. The binding patterns were visualized using a substrate solution containing 4-chloronaphtol, hydrogen peroxide, and ethanol in phosphate buffered saline solution. Image analysis of blots was carried out with Gel Doc 2000 system (Bio-Rad, Hercules, CA, USA) [75].

\subsubsection{Determination of Antioxidant Capacity}

Antioxidant capacity of ultra-heat-treated skimmed milk, milk with concentrated proteins and enzyme-treated milks was measured using the Ferric reducing ability of plasma method with respect of ascorbic acid [76]. Appropriate diluted $100 \mu \mathrm{L}$ of all kinds of milk samples with $2.9 \mathrm{~mL}$ of reagent (20 mM of ferric chloride: $10 \mathrm{mM}$ of 2,4,6-Tris(2-pyridyl)-s-triazine with $40 \mathrm{mM}$ of hydrochloric acid: $300 \mathrm{mM}$ of acetate buffer, $\mathrm{pH} 3.6=1: 1: 10$ (volume basis)) were incubated at temperature $\sim 35^{\circ} \mathrm{C}$ for $30 \mathrm{~min}$ in a water bath. Colorimetric determination was performed in room temperature $\left(\sim 25^{\circ} \mathrm{C}\right)$ with a UV-Vis spectrophotometer (Thermo ScientificTM, Waltham MA, USA). Spectrophotometric measurement was performed with wavelength $593 \mathrm{~nm}$.

\subsubsection{Estimation of Angiotensin-Converting-Enzyme Inhibitory Activity}

Enzymatic reaction mixture (final volume $200 \mu \mathrm{L}$ in each well), consisted of $50 \mathrm{mM}$ of sodium chloride, $100 \mathrm{mM}$ of TRIS $\mathrm{HCl}$ (pH 7), $10 \mu \mathrm{M}$ of zinc chloride, $15 \mu \mathrm{M}$ of substrate Abz-FRK(Dnp)-P, recombinant angiotensin converting enzyme, and milk samples (in a dilution range of 10 -fold to $10^{6}$-fold) was used in investigation. The amount of the recombinant angiotensin converting enzyme was chosen to result in about 10-fold activity than that in the human serum (dilution was 200 to 400 -fold from the stock). Reaction was initiated by the addition of substrate. Changes in fluorescent intensities were recorded in each 2-3 min and then changes were plotted as the function of time. These plots were fitted by a linear fit, and the slope was used to estimate enzyme activity (slope represents the change in fluorescent intensity in one minute). Activities in the absence of milk samples (uninhibited samples) were used as controls. The level of inhibition was calculated as $\%$ of uninhibited activity in each plate. Measurements were performed in a fluorescent plate reader (BMG Labtech, Ortenberg, Germany) at temperature $37^{\circ} \mathrm{C}$ in Corning 96 wells black and flat bottom plates (Corning, New York, USA). Changes in optical density were measured with wavelength $340 \mathrm{~nm}$ for at least $90 \mathrm{~min}$ with $5 \mathrm{~min}$ intervals [77].

\subsubsection{Determination of Protein Concentration}

Concentration of protein in ultra-heat-treated skimmed milk, milk with concentrated proteins, and enzyme-treated milks were determined by the Bradford assay. Appropriate dilution of $100 \mu \mathrm{L}$ of all kinds of milk samples with $3 \mathrm{~mL}$ of Bradford reagent were incubated at room temperature $\left(\sim 25^{\circ} \mathrm{C}\right)$ for $30 \mathrm{~min}$ in a water bath. Colorimetric determination was performed with wavelength $280 \mathrm{~nm}$ in a UV-Vis spectrophotometer (Thermo ScientificTM, Waltham, MA, USA). Assay was performed in room temperature $\left(\sim 25^{\circ} \mathrm{C}\right)$ and bovine serum albumin as a standard was used in assay [78]. 


\subsubsection{Microbiological Assay}

Antibacterial activity of ultra-heat-treated skimmed milk, milk with concentrated proteins, and enzyme-treated milks against Bacillus cereus and Staphylococcus aureus ATCC 6538 were investigated. Antibacterial activity was measured by agar well diffusion method. Sterile soybean casein digestive agar medium was used in the investigation. Freshly prepared (overnight grown culture) each culture was diluted with maximum recovery diluent $(\mathrm{MRD})$ solution $(8.5 \mathrm{~g}$ sodium chloride $+1 \mathrm{~g}$ peptone in $1 \mathrm{~L}$ of de-ionized water) to reach the bacterial concentration $10^{6}$ colony-forming units $\mathrm{mL}^{-1}$ in respective agar plate [79]. Bacterial culture was spread on solidified agar in respective petri plates (pour plated) and agar wells with diameter $5 \mathrm{~mm}$ were filled with $100 \mu \mathrm{L}$ of control milk and enzyme-treated milk samples. Petri plates were incubated at temperature $37^{\circ} \mathrm{C}$ for $48 \mathrm{~h}$ in a biological incubator $(\mathrm{HACH}$, Düsseldorf, Germany) [65,67]. The diameter of zone of inhibitions in microbial plates were measured by excluding the diameter of wells $(5 \mathrm{~mm})$ using a digital Vernier caliper (UEMATSU SHOKAI CO., LTD., Sendai, Japan).

\subsection{Statistical Analysis}

All experiments were performed at three times (technical triplicate). The mean value and standard deviation were calculated by Microsoft Excel (version 2013) (Microsoft Corporation, Washington, DC, USA). Subsequently, one-way analysis of variance method followed by the Tukey's post hoc test were performed to understand the significant difference $(P<0.05)$ between different groups. SPSS 15.0 (version 25.0) (IBM, Armonk, NY, USA) was used for statistical analysis.

\section{Results and Discussion}

\subsection{Concentrate Milk Proteins in Skimmed Milk by Membrane Filtration}

A ceramic tubular membrane with active filtration area $5 \times 10^{-3} \mathrm{~m}^{2}$ and pore size $5 \mathrm{~nm}$ was used to concentrate milk proteins in ultra-heat-treated skimmed milk by removing milk serum as a permeate. At room temperature and $\mathrm{pH} \sim 7$, casein micelle may have a mean radius of $50 \mathrm{~nm}$, whereas, the radius of whey proteins, such as $\alpha$-lactalbumin, $\beta$-lactoglobulin, bovine serum albumin, and tetrad immunoglobulin are $\sim 1.8 \mathrm{~nm}, \sim 1.8 \mathrm{~nm}, \sim 4 \mathrm{~nm}$, and $\sim 6 \mathrm{~nm}$, respectively [80]. Typically, ultra-heat-treated milk is prepared with temperature $135-145^{\circ} \mathrm{C}$ and treatment exposure time 1-8 s [81]. Due to heat treatment with high temperature, beside the Maillard reaction, sizes of proteins in milk are changed compared to their conventional sizes. When milk is heated at a temperature above $80{ }^{\circ} \mathrm{C}$, the tertiary structure of whey protein turns to unfold [82]. It has been reported that at a temperature higher than $80^{\circ} \mathrm{C}$, denaturation rate of $\alpha$-lactalbumin is faster than $\beta$-lactoglobulin's and denaturation of $\alpha$-lactalbumin is faster when $\beta$-lactoglobulin is present $[83,84]$. Subsequently, intramolecular highly reactive thiol groups, broken hydrophobic, and disulphide bonds may bind with covalent and hydrophobic bonds among themselves or with casein molecules, especially with $\mathrm{k}$-casein, present in periphery of casein micelle [85-87]. Furthermore, some whey proteins with sulfur containing thiol group ( $\mathrm{R}-\mathrm{SH}$ ) can bind with other proteins by covalent bonds. Bovine serum albumin and $\beta$-lactoglobulin [88,89], and $k$-casein and $\beta$-lactoglobulin [90-92] may bind together due to heat treatment. However, $\alpha$-lactalbumin does not contain -SH group, it may conjugate with caseins in presence of $\beta$-lactoglobulin [93]. In addition, heat treatment may promote the formation of isopeptide bond between lysine and glutamine ( $\mathrm{N}-\varepsilon-(\gamma$-glutamyl)-lysine) or asparagine ( $\mathrm{N}-\varepsilon$-( $\beta$-aspartyl)-lysine) among different proteins, present in liquid milk protein concentrate [94-96]. Due to faster thermodenaturation of $\alpha$-lactalbumin in presence of $\beta$-lactoglobulin, it may completely conjugate with casein micelle [80]. Therefore, it might expect that most of whey proteins have chance to conjugate with casein and the size of casein micelle might increase. On the other hand, due to intermolecular conjugation of whey proteins, the size of whey proteins might increase. Because of it, most of the proteins might reject by the nanofiltration membrane and residual (unbounded) whey proteins and lactose might permeate with milk serum through membrane pores during nanofiltration. 
As nanofiltration is a pressure-driven membrane separation process, a gel layer is developed on the membrane surface during separation process. A detailed investigation was performed to reduce the development of gel layer on the membrane surface by changing TMP and RFR. In Table 1, initial permeate flux and percentage change of permeate flux for different TMPs and RFRs are reported.

Table 1. Difference of pressure, initial permeate flux and percentage change of permeate flux for different trans-membrane pressures (TMPs) and retention flow rates (RFRs) in absence and presence of static turbulence promoter. Results are represented by mean value with standard deviation ( \pm values). In superscript, dissimilar alphabet represents the significant difference between results, evaluated by the Tukey's post hoc method.

\begin{tabular}{|c|c|c|c|c|c|c|c|}
\hline \multirow[b]{2}{*}{$\begin{array}{l}\text { TMP } \\
\text { (Bar) }\end{array}$} & \multirow[b]{2}{*}{$\begin{array}{c}\text { RFR } \\
\left(L \cdot h^{-1}\right)\end{array}$} & \multicolumn{3}{|c|}{ Without Static } & \multicolumn{3}{|c|}{ With Static } \\
\hline & & $\begin{array}{c}\Delta p \\
\text { (Bar) }\end{array}$ & $\begin{array}{c}J_{\text {initial }} \\
\left(\mathbf{L} \cdot \mathbf{h}^{-1} \cdot \mathrm{m}^{-2}\right)\end{array}$ & $\Delta J(\%)$ & $\begin{array}{l}\Delta p \\
\text { (Bar) }\end{array}$ & $\begin{array}{c}J_{\text {initial }} \\
\left(\mathbf{L} \cdot \mathbf{h}^{-1} \cdot \mathbf{m}^{-2}\right)\end{array}$ & $\Delta J(\%)$ \\
\hline 2 & 100 & 0.1 & $8.06 \pm 1^{a}$ & $41.69 \pm 1.27^{\mathrm{a}}$ & 0.3 & $15.58 \pm 1.1^{\mathrm{a}}$ & $32.33 \pm 1.25^{a}$ \\
\hline 2 & 200 & 0.1 & $8.2 \pm 1.2^{\mathrm{a}}$ & $37.39 \pm 2.35^{\mathrm{ab}}$ & 0.7 & $15.88 \pm 1^{\mathrm{a}}$ & $31.70 \pm 2.5^{\mathrm{a}}$ \\
\hline 3 & 100 & 0.1 & $13.45 \pm 1.1^{b}$ & $36.95 \pm 1.55^{\mathrm{a}, \mathrm{b}}$ & 0.3 & $34.22 \pm 1.08^{b}$ & $24.01 \pm 1.19^{b}$ \\
\hline 3 & 200 & 0.1 & $18 \pm 3.9^{b}$ & $33.33 \pm 2.79^{b}$ & 0.7 & $34.55 \pm 1.02^{b}$ & $23.61 \pm 2.31^{b}$ \\
\hline
\end{tabular}

It is observed that permeate flux of serum was increased with the increase of TMP, because TMP provided driving force on the membrane surface. At higher TMP, the formation of gel layer on membrane surface was reduced and convective flux of serum increased due to the driving force on the membrane surface. For a similar reason, the percentage change of permeate flux decreased with the increase of TMP. As an outcome, concentration of protein in retentate side of the membrane, increased. As an example, after volume reduction 2 , concentrations of protein in storage tank of the membrane module were $59.2 \mathrm{~g} \cdot \mathrm{L}^{-1}$ and $42 \mathrm{~g} \cdot \mathrm{L}^{-1}$, when filtration process was performed with TMP $3 \mathrm{bar}, \mathrm{RFR} 100 \mathrm{~L} \cdot \mathrm{h}^{-1}$ and 2 bar, RFR $100 \mathrm{~L} \cdot \mathrm{h}^{-1}$, respectively. At constant TMP, permeate flux was increased at higher RFR; however, results were not statistically significant. The tubular membrane had the lower surface area to volume ratio and, therefore, high feed flow rate promoted permeation. In cross-flow module, fluid on the membrane surface flowed with horizontal direction on the membrane surface with higher velocity and created more turbulence at higher RFR. Due to the sweeping action of fluid on the membrane surface, the deposition of solute molecules on the membrane surface reduced. Lower deposition of solute molecules on the membrane surface reduced the formation of concentration polarization and gel layer resistance, accompanied by the increase rate of permeation. Moreover, it was found that rate of flux declination was lower when the static turbulence promoter was used in the filtration process. The static turbulence promoter offered tangential velocity of fluid across the membrane surface, which created turbulence and vorticity of fluid on the membrane surface. Furthermore, the static turbulence promoter provided centrifugal force on the fluid, which contributed driving force on the membrane surface. All these factors reduced the deposition of solute molecules on the membrane surface and membrane gel layer resistance, which offered higher permeate flux in filtration process. As permeate flux was significantly higher in the static turbulence promoter-implemented filtration process, specific energy consumption was studied with different TMPs and RFRs in static turbulence promoter-implemented filtration process (Figure 3).

At constant TMP, values of specific energy consumption in filtration process were significantly low at lower RFR. When RFR was $200 \mathrm{~L} \cdot \mathrm{h}^{-1}$, permeate flux was not significantly increased compared to $100 \mathrm{~L} \cdot \mathrm{h}^{-1}$ because RFR could not provide driving force on the membrane surface. Therefore, permeate flux was not significantly increased compared to pressure drop at two opposite ends of the membrane. Filtration process with static turbulence promoter, higher TMP and lower RFR, tangential velocity of fluid across the membrane surface, driving, and centrifugal force on the fluid were generated. As an outcome, permeate flux was increased and pressure drop was reduced. Protein concentration in the retentate side of the membrane is also represented in Figure 3. It is noted that concentration of 
protein in the retentate side was higher with TMP 3 bar compared to TMP 2 bar. Protein concentration increased due to higher permeation of serum through membrane pores at higher TMP. Concentration of protein in retentate was not significantly increased at RFR $200 \mathrm{~L} \cdot \mathrm{hh}^{-1} \mathrm{compared}$ to $100 \mathrm{~L} \cdot \mathrm{hh}^{-1}$, because RFR could not generate the driving force on the membrane surface and osmotic pressure. In Figure 4, time histories of the permeate flux, without and with the static turbulence promoter, are presented.

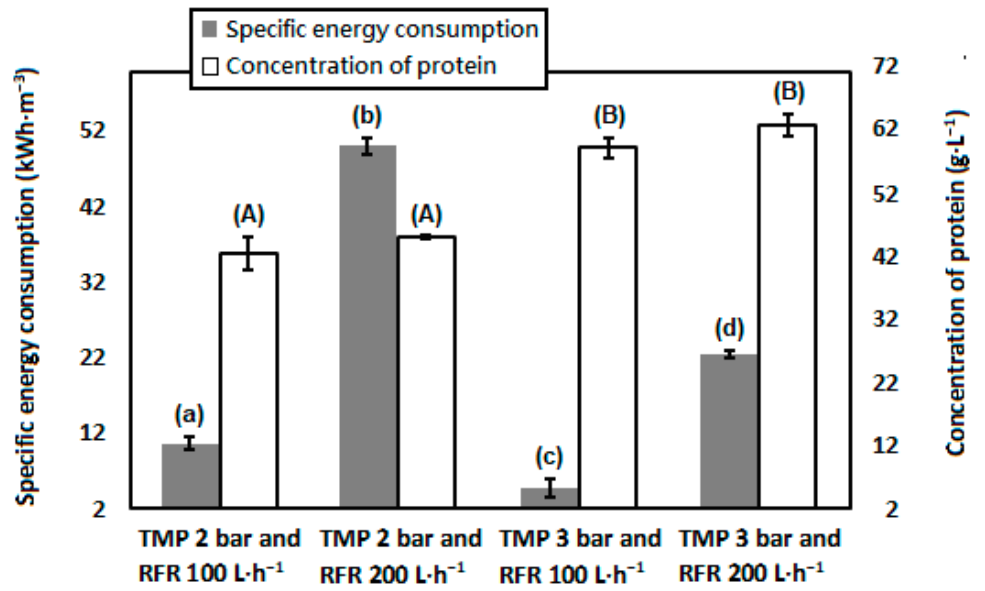

Figure 3. Specific energy consumption and concentration of protein in the retentate side of membrane for different trans-membrane pressures (TMPs) and retention flow rates (RFRs) in static turbulence promoter-implemented filtration process. Results are represented by mean value with standard deviation ( \pm values). In superscript, dissimilar alphabet represents the significant difference between results, evaluated by the Tukey's post hoc method.
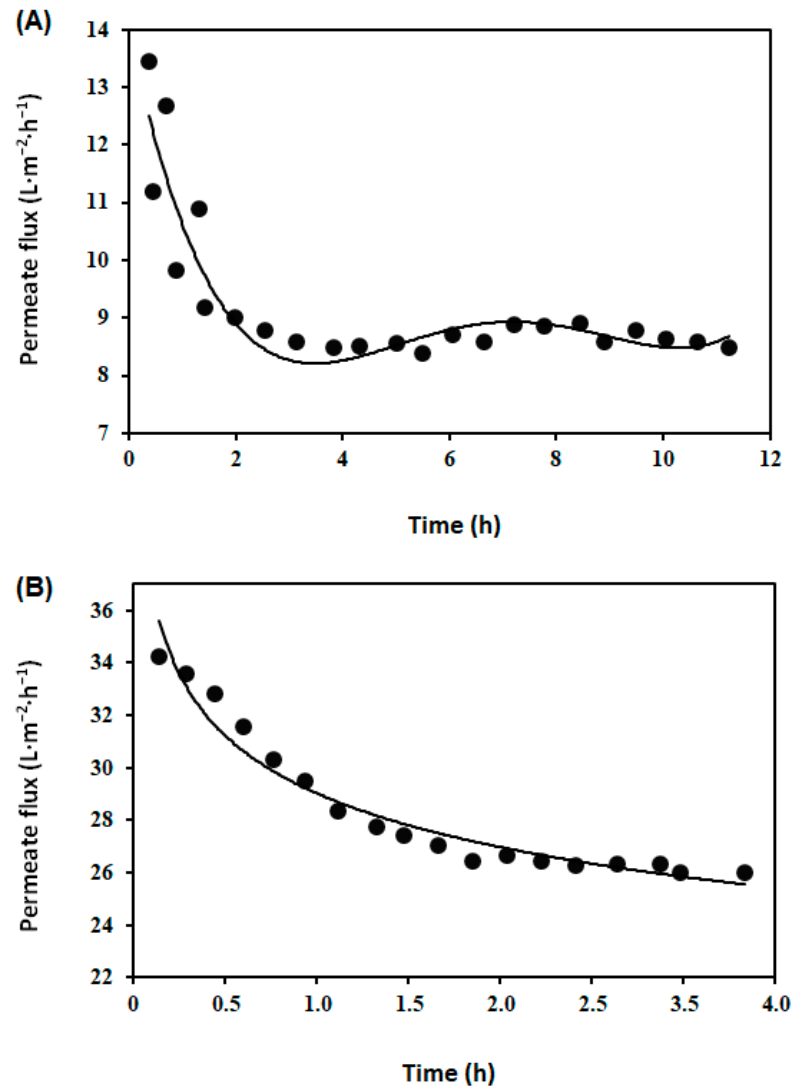

Figure 4. Time history of permeate flux without the static turbulence promoter (A) and with the static turbulence promoter $(\mathbf{B})$. 
It was noted that when the static turbulence promoter was used in membrane filtration process, rate of flux declination and filtration time were reduced because the formation of gel layer was reduced in the presence of static turbulence promoter inside of tubular membrane.

\subsection{Molecular Weight of Different Proteins in Concentrated Milk and Their Enzymatic Hydrolysis}

Analysis of molecular weight of different proteins in concentrated milk was performed using UV chromatogram, total ion chromatogram (TIC), and deconvoluted mass spectrum of observed protein spectra (Figure 5).

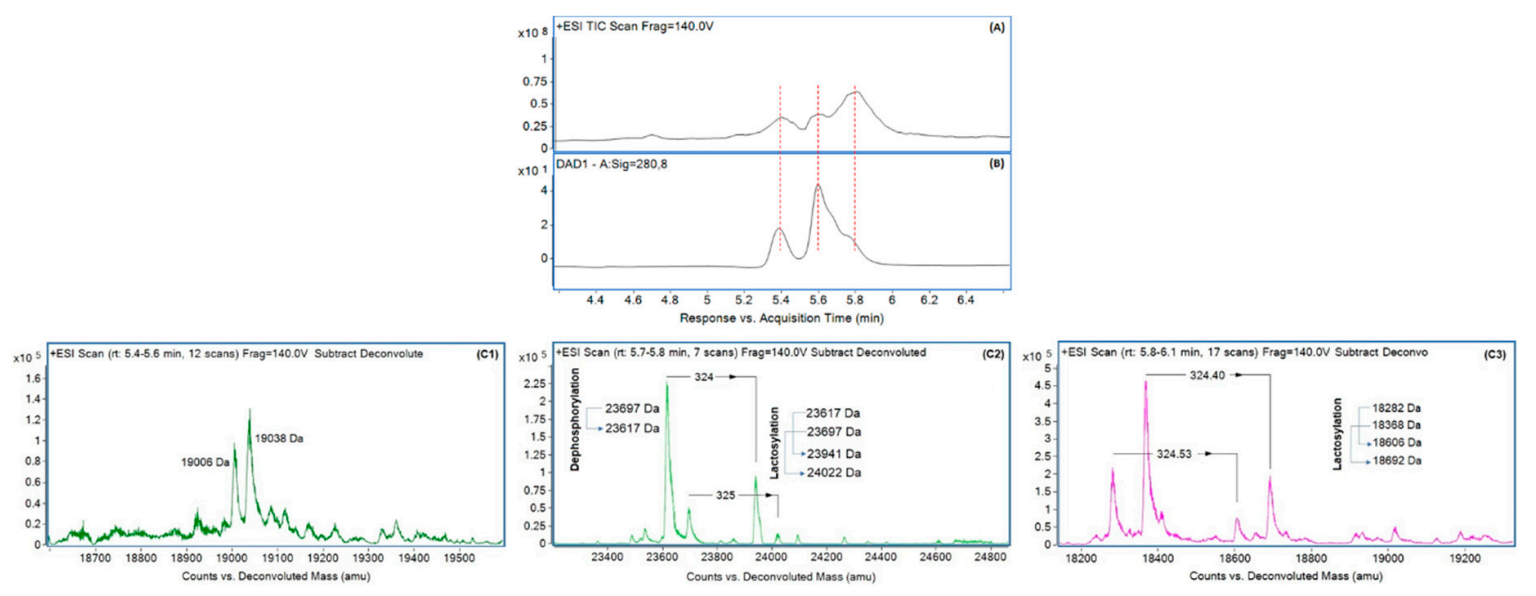

Figure 5. Results of liquid chromatography-mass spectrometry; (A) UV chromatogram of proteins in concentrated milk, (B) total ion chromatogram of proteins in concentrated milk, (C) deconvoluted mass spectra of different proteins, peaks appear at retention time $5.4 \mathrm{~min}(\mathbf{C 1}), 5.6 \mathrm{~min}(\mathbf{C} 2)$, and $5.8 \mathrm{~min}(\mathbf{C} 3)$.

Major proteins provided pronounced UV signal at $280 \mathrm{~nm}$. In that UV wavelength, three peaks at $5.4 \mathrm{~min}, 5.6 \mathrm{~min}$, and $5.8 \mathrm{~min}$ retention times were detected. Corresponding MS (TIC) signals are fully matched with UV peaks and deconvolution of each chromatographic peak spectrum was performed. Deconvoluted mass spectrum of proteins appeared in the retention time 5.4 min is provided in Figure 5(C1). In this figure, it is noted that there are two major deconvoluted masses, such as $19006 \mathrm{Da}$ and $19038 \mathrm{Da}$. According to the previously published results, they might represent $\mathrm{K}$-casein. Deconvoluted mass spectrum of proteins appeared in retention time $5.6 \mathrm{~min}$ is provided in Figure 5(C2). In this figure, two major deconvoluted masses, such as $23617 \mathrm{Da}$ and $23697 \mathrm{Da}$ are observed. Comparing with the previously published results, they might represent $\alpha$-casein [97]. Protein with molecular mass 23617 Da might be dephosphorylated form of $\alpha$-casein (-80 Da mass shift from $23697 \mathrm{Da}$ ). Different types of caseins have a high degree of phosphorylation, which is generally affected by high temperature treatment during milk processing [98]. Interestingly, two protein with molecular mass shift +324 Da were observed in Figure 5(C2). These proteins with molecular mass $23941 \mathrm{Da}$ and $24022 \mathrm{Da}$ might be the lactosylated form of their original protein. Lactosylation of protein took place due to heat treatment during ultra-heat-treated milk production and, subsequently, their storage. The Amadori product $\varepsilon$-lactulosyllysine is produced by free $\varepsilon$-amino group of lysine in protein chain and milk sugar lactose [99]. It has been reported that protein become more hydrophilic due to addition of lactose in its structure, which results a shift to lower retention time $[100,101]$. Deconvoluted mass spectrum of proteins appeared in retention time 5.8 min is provided in Figure 5(C3). In this figure, two major deconvoluted masses, such as $18282 \mathrm{Da}$ and $18368 \mathrm{Da}$, along with their lactosylated form with molecular mass $18606 \mathrm{Da}$ and $18692 \mathrm{Da}$ are observed. According to the already published results, the original protein might represent $\beta$-lactoglobulin [97]. According to the electrophoretic pattern, represented in Figure 6, ultra-heat-treated skimmed milk and milk with concentrated proteins may have had immunoglobulin, lactoferrin, lactoperoxidase, bovine serum albumin, $\alpha$-casein, conjugated $\beta$-lactoglobulin, and $\alpha$-lactalbumin or dimer $\beta$-lactoglobulin, $\beta$-casein, 
$\gamma$-casein, $\mathrm{k}$-casein, $\beta$-lactoglobulin, and $\alpha$-lactalbumin with molecular weight $\sim 150 \mathrm{kDa}, \sim 80 \mathrm{kDa}$, $\sim 78 \mathrm{kDa}, \sim 66 \mathrm{kDa}, \sim 35 \mathrm{kDa}, \sim 34 \mathrm{kDa}, \sim 25 \mathrm{kDa}, \sim 22 \mathrm{kDa}, \sim 20 \mathrm{kDa}, \sim 18 \mathrm{kDa}$, and $\sim 14 \mathrm{kDa}$, respectively. Some other investigators also published similar results [83,102-104].

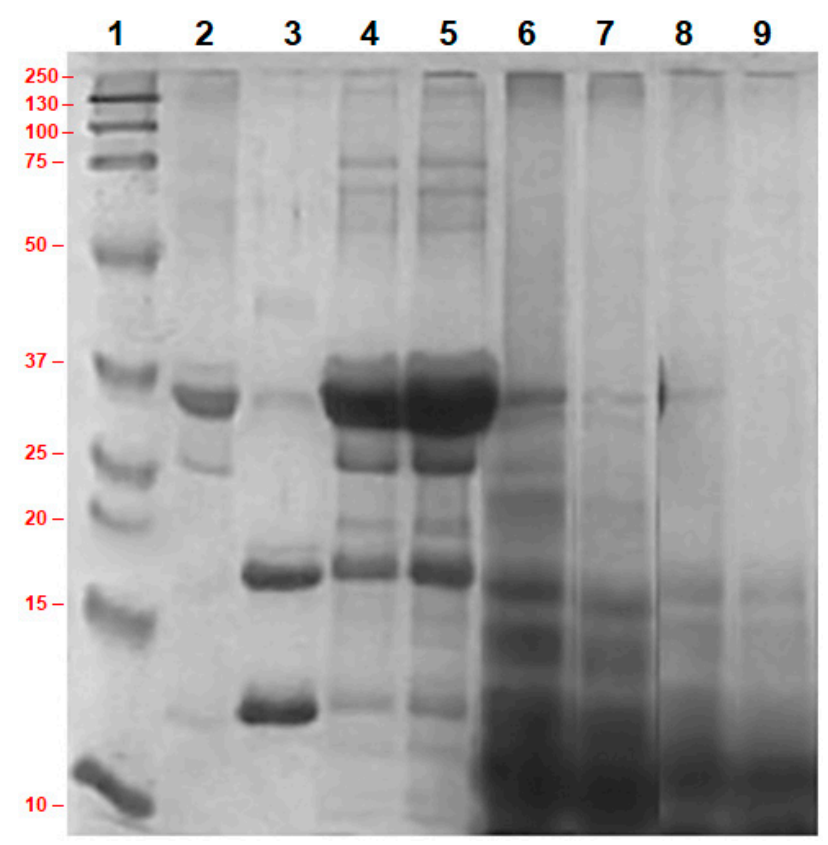

Figure 6. Sodium dodecyl sulfate polyacrylamide gel electrophoresis (SDS-PAGE) image of ultra-heat-treated skimmed milk, milk with concentrated proteins and milk with concentrated proteins after enzyme treatment; lane 1: marker protein, lane 2: standard casein, lane 3: standard $\alpha$-lactalbumin and $\beta$-lactoglobulin, lane 4: ultra-heat-treated skimmed milk, lane 5: concentrated ultra-heat-treated skimmed milk, lane 6: concentrated liquid milk protein treated with $0.008 \mathrm{~g} \mathrm{~L}^{-1}$ of trypsin, lane 7: concentrated liquid milk protein treated with $0.016 \mathrm{~g} \mathrm{~L}^{-1}$ of trypsin, lane 8:concentrated liquid milk protein treated with $0.032 \mathrm{~g} \mathrm{~L}^{-1}$ of trypsin, lane 9: concentrated liquid milk protein treated with $0.064 \mathrm{~g} \mathrm{~L}^{-1}$ of trypsin.

In the PAGE image, hydrophobic protein conjugate with molecular weight $\sim 34 \mathrm{kDa}$ is clearly visualized. It was reported that due to heat treatment of skimmed milk, sometimes $\beta$-lactoglobulin and $\alpha$-lactalbumin might participate in intermolecular thiol-disulphide bond interchange to produce covalently bonded hydrophobic aggregates [105]. Another group of investigators reported that at temperature more than $90^{\circ} \mathrm{C}, \beta$-lactoglobulin might present with disulphide-bonded dimer with molecular weight $\sim 34 \mathrm{kDa}$ and monomer [106]. However, some researchers reported about the formation of dimer $\alpha$-lactalbumin with molecular weight $\sim 28 \mathrm{kDa}$ [107], but it was not found in our investigation. From the above discussion, it may say that the molecular weight of casein in concentrated milk, determined by SDS-PAGE and mass-spectroscopy is not directly comparable. It may explain by the fact that the electrophoretic mobility of caseins in electrophoresis gel is lower than expected from their molar mass [108]. It may be justified by the fact that phosphorylation [109] and lactosylation of caseins [73] change the migration of casein molecules in electrophoresis gel. However, in SDS-PAGE, several protein aggregates were present, they were absent in mass-spectrum. The possible reason is that dissociation of protein molecules and disruption of any type of protein aggregate might done by reducing agents DTT and chaotropic agent urea in sample preparation for mass-spectroscopy [110].

Without any contradiction, it was found that the numbers of peptide bands were increased due to tryptic digestion of milk proteins (lane 6-9). The hydrolysis of concentrated milk proteins was dose-dependent because it was noted that band numbers with lower molecular weight were increased gradually with increase of enzyme concentration in hydrolysis reaction. Immunoglobulin were hydrolyzed at more than $99 \%$ when concentration of trypsin was increased from $0.016 \mathrm{~g} \cdot \mathrm{L}^{-1}$ to 
$0.032 \mathrm{~g} \cdot \mathrm{L}^{-1}$. Lactoferrin, lactoperoxidase, and bovine serum albumin were hydrolyzed at more than $99 \%$ due to treatment with $0.008 \mathrm{~g} \cdot \mathrm{L}^{-1}$ of trypsin. Furthermore, $\mathrm{k}$-casein and $\beta$-casein were hydrolyzed at more than $99 \%$ when concentration of trypsin was increased from $0.008 \mathrm{~g} \cdot \mathrm{L}^{-1}$ to $0.016 \mathrm{~g} \cdot \mathrm{L}^{-1}$, whereas $\alpha$-casein was retained. $\alpha$-casein was hydrolyzed at more than $99 \%$ with $0.064 \mathrm{~g} \cdot \mathrm{L}^{-1}$ of trypsin. This can be justified by the fact that $\alpha$-casein might has less chance to participate in enzymatic reaction because in the interior part of casein micelle, calcium phosphate clusters bind with the phosphoseryl residues of $\alpha_{\mathrm{s}}$-casein and $\beta$-casein, whereas $\mathrm{k}$-casein was present in the periphery of casein micelle and received chance to participate in enzymatic reaction [111]. Due to partial hydrolysis of $\beta$-casein with $0.008 \mathrm{~g} \cdot \mathrm{L}^{-1}$ of trypsin, some peptone and $\gamma$-casein with molecular weight $\sim 22 \mathrm{kDa}$ might produce and they were hydrolyzed when milk with concentrated proteins was treated with $0.032 \mathrm{~g} \cdot \mathrm{L}^{-1}$ of trypsin. Dimer $\beta$-lactoglobulin with molecular weight $\sim 32 \mathrm{kDa}$ was hydrolyzed when trypsin was increased from $0.016 \mathrm{~g} \cdot \mathrm{L}^{-1}$ to $0.032 \mathrm{~g} \cdot \mathrm{L}^{-1}$.

\subsection{Antioxidant Capacity}

Antioxidant capacity of milk with concentrated proteins was $167.35 \pm 9.8 \mathrm{mg}$ equivalent ascorbic acid $\mathrm{L}^{-1}$ and it was increased after enzyme treatment. In Figure 7, it is noted that change of antioxidant capacity in enzyme-treated milks was dose-dependent. Similar types of findings were also published by other researchers $[62,63]$.

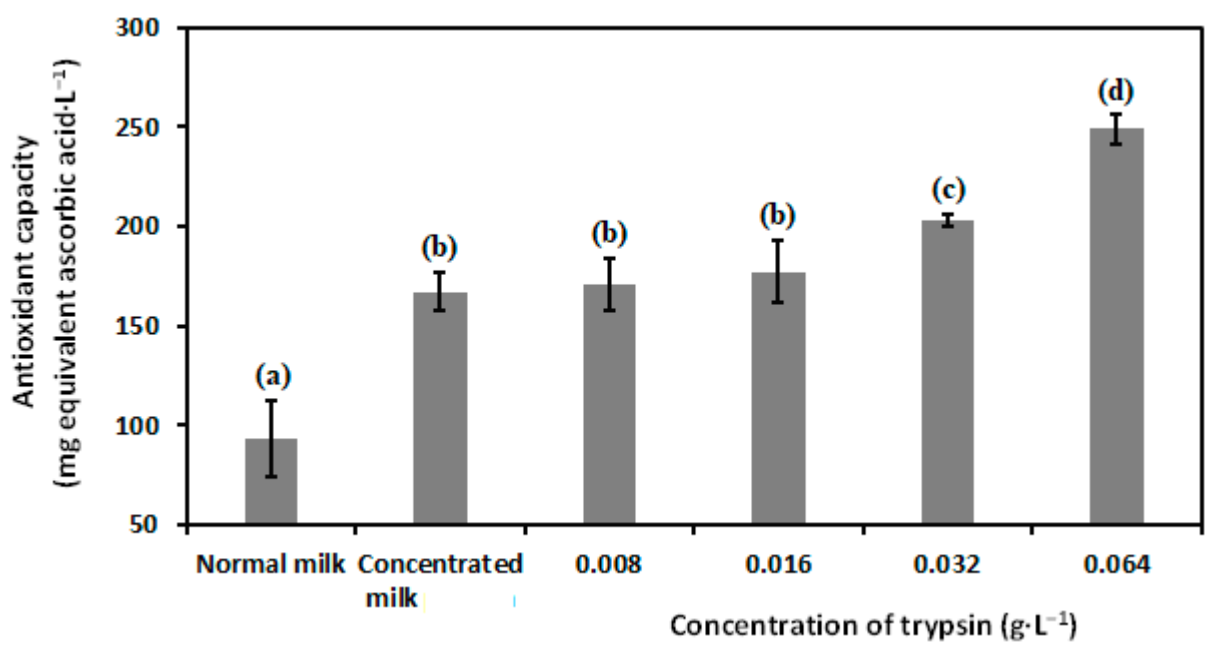

Figure 7. Antioxidant capacity of ultra-heat-treated skimmed milk, milk with concentrated proteins, and milk with concentrated proteins after enzyme treatment. Results are represented by mean value with standard deviation ( \pm values). In superscript, dissimilar alphabet represents the significant difference between results, evaluated by the Tukey's post hoc method.

Trypsin is a serine endopeptidase, consisting of three amino acids, such as His 57, Ser 195, and Asp 102 in catalytic triad. In amino acid sequence, trypsin cleaves between the carboxyl group of basic amino acid lysine or arginine in $\mathrm{N}$ terminal position and the amino group of the adjacent amino acid with hydrophobic side chain in $\mathrm{C}$ terminal position. This cleavage does not occur when lysine or arginine is followed by proline. Adjacent hydrophobic amino acid, such as alanine, isoleucine, leucine, methionine, phenylalanine, valine, proline, and glycine in peptide chain, derived from milk proteins by tryptic hydrolysis, offered reducing activity towards ferric ion $[64,112,113]$.

\subsection{Angiotensin Converting Enzyme-Inhibitory Activity}

Angiotensin converting enzyme inhibitory activity of ultra-heat-treated skimmed milk and milk with concentrated proteins was negligible. Inhibitions of angiotensin converting enzyme were $\sim 15 \%$ and $\sim 6 \%$ for ultra-heat-treated skimmed milk and milk with concentrated proteins, respectively (Figure 8A). Our finding was similar in accordance with other researchers [114,115]. 

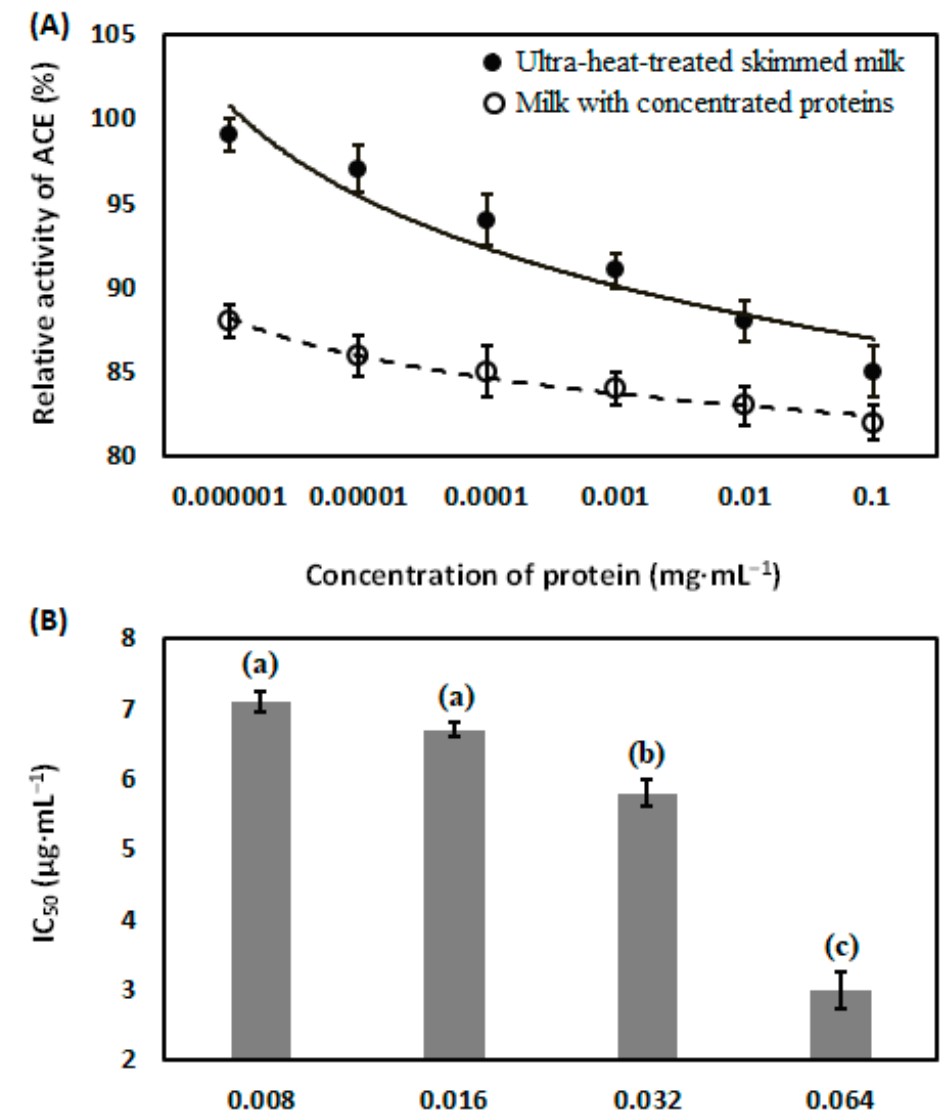

Concentration of trypsin $\left(\mathrm{g} \cdot \mathrm{L}^{-1}\right)$

Figure 8. Angiotensin converting enzyme (ACE)-inhibitory activity of ultra-heat-treated skimmed milk and milk with concentrated proteins (A), and values of $\mathrm{IC}_{50}$ in milk with concentrated proteins after enzyme treatment (B). Results are represented by mean value with standard deviation ( \pm values). In superscript, dissimilar alphabet represents the significant difference between results, evaluated by the Tukey's post hoc method.

It can be justified by the fact that interaction between active side of angiotensin converting enzyme and native milk proteins might not be facilitated, because steric hindrance might present [116]. Angiotensin converting enzyme in concentrated milk proteins significantly increased after trypsin treatment. Similar types of findings were reported by other investigators $[117,118]$. Changes of $\mathrm{IC}_{50}$ value in liquid milk protein concentrate due to enzyme treatment were dose-dependent (Figure 8B). Because of tryptic hydrolysis of milk proteins, active sides in low molecular weight peptides were exposed and interaction with angiotensin converting enzyme was facilitated. It was reported that peptides with hydrophobic amino acids, such as proline, tryptophan, tyrosine, and phenylalanine at C-terminal position, are able to bind with angiotensin converting enzyme $[119,120]$. In our investigation, more than $95 \%$ inhibition was not achieved. This can be justified by the fact that angiotensin converting enzyme inhibitory peptides, produced by tryptic hydrolysis of milk proteins might change the structural configuration of angiotensin converting enzyme, which might not favorable for interaction between substrate and angiotensin converting enzyme [121].

\subsection{Antibacterial Activity}

Antibacterial activity (represented in zone of inhibition) of enzyme-treated liquid milk protein concentrate towards Bacillus cereus and Staphylococcus aureus was proven. No zone of inhibition was found when milk with concentrated proteins was tested. In Figure 9, radius of zone of inhibition 
represented the antibacterial activity of milk with concentrated proteins after enzyme treatment is mentioned.

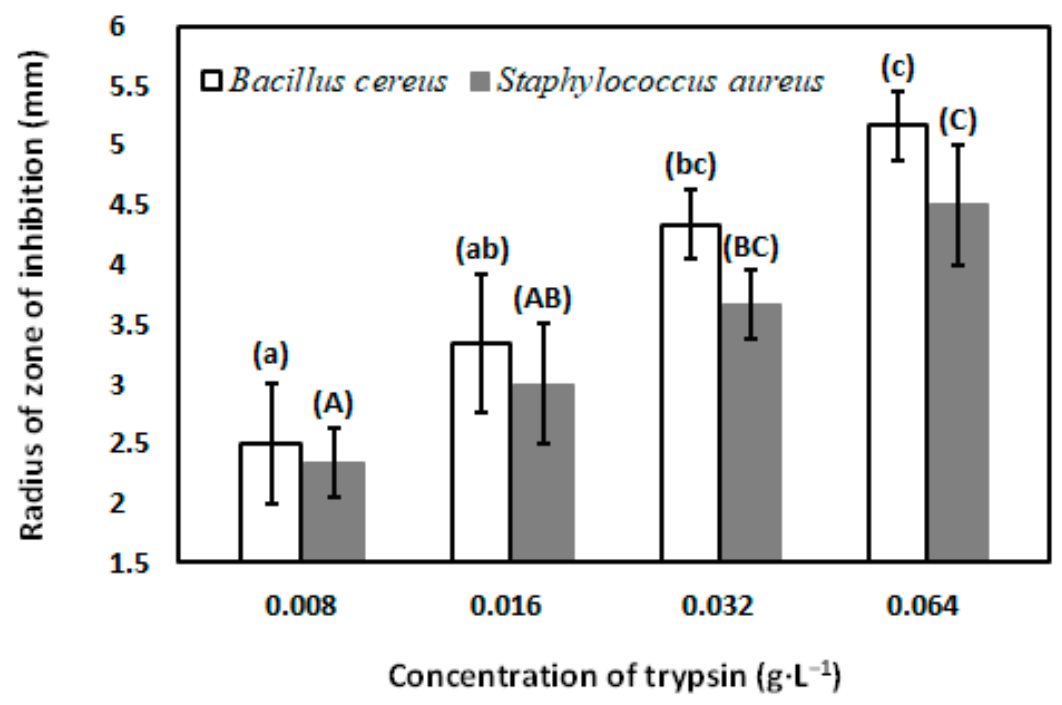

Figure 9. Antibacterial activity of milk with concentrated proteins after enzyme treatment. Results are represented by mean value with standard deviation ( \pm values). Superscript dissimilar alphabet represents the significant difference between results, evaluated by the Tukey's post hoc method.

Zone of inhibition (radius of inhibition zone) was significantly increased when concentration of trypsin was increased from $0.008 \mathrm{~g} \cdot \mathrm{L}^{-1}$ to $0.032 \mathrm{~g} \cdot \mathrm{L}^{-1}$ during hydrolysis of liquid milk protein concentrate. It was found that for Bacillus cereus, values of zone of inhibition (radius of inhibition zone) were $2.5 \pm 0.5 \mathrm{~mm}$ and $5.2 \pm 0.3 \mathrm{~mm}$, when concentrated milk protein was treated with $0.008 \mathrm{~g} \cdot \mathrm{L}^{-1}$ and $0.064 \mathrm{~g} \cdot \mathrm{L}^{-1}$ of trypsin, respectively. For Staphylococcus aureus, values of zone of inhibition (radius of inhibition zone) were $2.3 \pm 0.03 \mathrm{~mm}$ and $4.5 \pm 0.5 \mathrm{~mm}$ when concentrated milk protein was treated with $0.008 \mathrm{~g} \cdot \mathrm{L}^{-1}$ and $0.064 \mathrm{~g} \cdot \mathrm{L}^{-1}$ of trypsin, respectively. Several biochemical mechanisms about antibacterial activity of enzyme-treated liquid milk protein concentrate were reported. Trypsin cleaves the peptide bond at the $\mathrm{C}$-terminus of lysin and arginine, when the $\mathrm{N}$ terminus is not a proline. Several peptides with hydrophobic, hydrophilic or amphipathic amino acids, produced due to tryptic hydrolysis of milk proteins. These peptides may interact with peptidoglycan in bacterial cell membrane, create a complex with bacterial cell wall components, and, subsequently, create pores in bacterial cell membrane. These pores might expedite the permeabilization of cellular contents to the abiotic environment and subsequently, destruction of cell. It has been also reported that interaction between bacterial cell membrane with antibacterial peptides frequently leads to lipid segregation in the cell membrane. It leads to delocalization of essential membrane proteins, increase membrane permeability, inhibit cell division, followed by cellular death [122,123].

\subsection{Allergenicity}

Immunoblotting, a combination of gel electrophoresis and antigen-antibody reaction was performed with positive pooled human sera to understand the allergenic potentiality of proteins, present in liquid milk protein concentrate. It was reported that major cow milk allergens belong to the casein fraction $\left(\alpha_{\mathrm{S1}^{-}}, \alpha_{\mathrm{S}^{-}}, \beta-\right.$, and $\mathrm{k}$-casein), and whey proteins $\alpha$-lactalbumin and $\beta$-lactoglobulin; however, lactoferrin, bovine serum albumin and immunoglobulins, which are present with lower quantities in cow milk, have importance in allergenic reaction [22]. In present investigation, it was noted that however, immunoglobulin, lactoferrin, lactoperoxidase, bovine serum albumin, and casein had strong interaction with antibody, monomeric $\beta$-lactoglobulin had weak interaction, and monomeric $\alpha$-lactalbumin had no detectable interaction (Figure 10). 


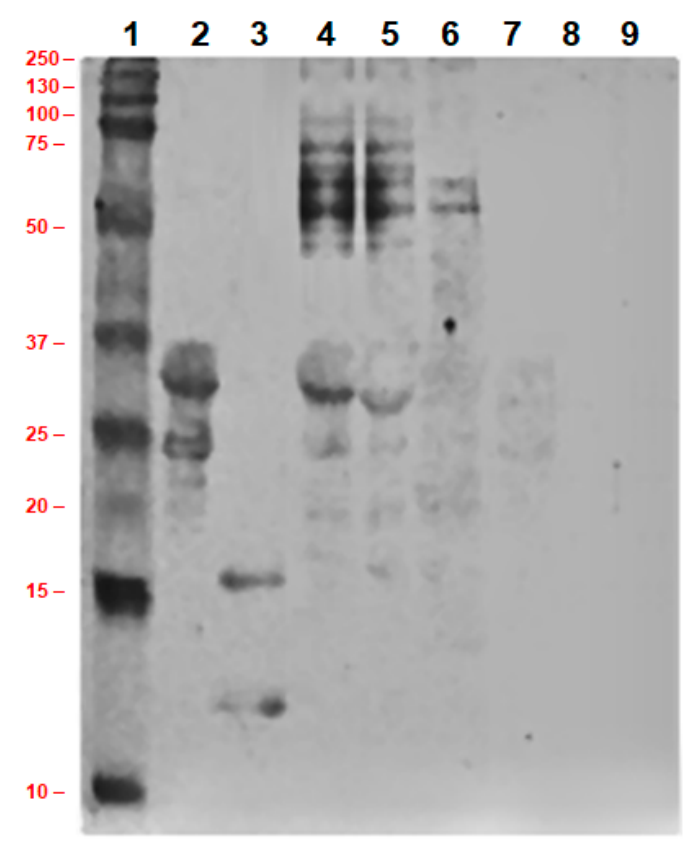

Figure 10. Immunoblot of ultra-heat-treated skimmed milk, milk with concentrated proteins and milk with concentrated proteins after enzyme treatment; lane 1: marker protein, lane 2: standard casein, lane 3: standard $\alpha$-lactalbumin and $\beta$-lactoglobulin, lane 4: ultra-heat-treated skimmed milk, lane 5: concentrated ultra-heat-treated skimmed milk, lane 6: concentrated liquid milk protein treated with $0.008 \mathrm{~g} \cdot \mathrm{L}^{-1}$ of trypsin, lane 7 : concentrated liquid milk protein treated with $0.016 \mathrm{~g} \cdot \mathrm{L}^{-1}$ of trypsin, lane 8: concentrated liquid milk protein treated with $0.032 \mathrm{~g} \cdot \mathrm{L}^{-1}$ of trypsin, lane 9: concentrated liquid milk protein treated with $0.064 \mathrm{~g} \cdot \mathrm{L}^{-1}$ of trypsin.

This result can be explained by the following justifications. As the experiment was performed with ultra-heat-treated skimmed milk, due to heat treatment most of $\alpha$-lactalbumin and $\beta$-lactoglobulin were unfolded, and allergenic epitopes in $\alpha$-lactalbumin and $\beta$-lactoglobulin were destroyed [104,124]. Allergenic epitopes in higher molecular weight proteins, such as bovine serum albumin, lactoperoxidase, conjugated $\alpha$-lactalbumin, and $\beta$-lactoglobulin or $\alpha$-casein were not fully affected during heat treatment because their denaturation temperatures were quite high [104,125]. In an investigation with 20 children (median age 4 months), it was also found that, however, $\alpha_{\mathrm{S} 1}$-casein, $\alpha_{\mathrm{S} 2}$-casein, $\beta$-casein, $\kappa$-casein, bovine serum albumin, Immunoglobulin-G heavy chain, and lactoferrin had allergenic cross-linking, $\alpha$-lactalbumin did not have any allergenic activity [126]. However, all proteins in concentrated milk, except $\alpha$-lactalbumin, were immunoreactive; they lost allergenic activity due to enzymatic hydrolysis. Residual immunoreactivity of caseins and dimeric $\beta$-lactoglobulin or conjugated $\alpha$-lactalbumin- $\beta$-lactoglobulin were still present at $0.016 \mathrm{~g} \cdot \mathrm{L}^{-1}$ of trypsin treatment. They lost allergenic potentiality when $0.032 \mathrm{~g} \cdot \mathrm{L}^{-1}$ of trypsin was used in enzymatic reaction.

\subsection{Superiority of the Process}

After skillful experiment to prepare liquid skimmed milk protein concentrate, the superior operation strategy was trans-membrane pressure 3 bar, retention flow rate $100 \mathrm{~L} \cdot \mathrm{h}^{-1}$, and implementation of a static turbulence promoter within a tubular ceramic membrane with pore size $5 \mathrm{~nm}$ and filtration area $5 \times 10^{-3} \mathrm{~m}^{2}$. In the present investigation, a cross-flow membrane module was adopted and batch-mode filtration was performed with volume reduction factor 2 . To prepare milk protein concentrate, polymeric spiral wound $[19,127,128]$, single flat sheet $[13,129,130]$, and tubular [131] membranes were used. Furthermore, ceramic tubular membrane was used to prepare milk protein concentrate by several investigators [132-136]. Single stage membrane filtration [19,127,129,131,136] and ultrafiltration with diafiltration were used by several investigators to prepare milk protein 
concentrate $[137,138]$. Both continuous and discontinuous diafiltration were adopted to reduce major whey proteins, such as $\alpha$-lactalbumin and $\beta$-lactoglobulin from casein fraction by ultrafiltration or nanofiltration membrane. In continuous diafiltration process, sterilize water was added to the feed tank to maintain the feed volume, whereas discontinuous diafiltration was introduced in the process when the feed concentration reached to a certain level to overcome the high viscosity of feed and protect the membrane by fouling. However, milk protein concentrate was prepared by both polymeric and ceramic membrane; flux declination is a considerable drawback. To overcome this issue, stepwise increase of TMP was adopted in sometimes [131,134] and it may feel that in respect of energy consumption, this approach is not appreciable. In our investigation, due to application of the static turbulence promoter reduction of permeate flux was remarkably low. The experiment was started with $1 \mathrm{~L}$ of milk in the feed tank and after volume reduction factor 2 without diafiltration, initial permeate flux $34 \mathrm{~L} \cdot \mathrm{m}^{-2} \cdot \mathrm{h}^{-1}$ reduced to $26 \mathrm{~L} \cdot \mathrm{m}^{-2} \cdot \mathrm{h}^{-1}$, i.e., only $24 \%$ reduction in permeate flux. During filtration, consumption of mechanical energy, contributed by fluid flow rate and TMP was $4.9 \mathrm{kWh} \mathrm{m}^{-3}$. However, in SDS-PAGE image all proteins in concentrated milk were clearly visualized, but in immunoblot it was found that monomeric $\alpha$-lactalbumin and $\beta$-lactoglobulin did not offer allergenicity, due to change of their structural configuration during heat treatment. Hence, diafiltration was not required to fulfil the objective of present investigation. Filtration process without diafiltration might be reduced the water consumption and process time. According to our experimental finding, application of $0.032 \mathrm{~g} \cdot \mathrm{L}^{-1}$ of trypsin to liquid milk protein concentrate at temperature $40{ }^{\circ} \mathrm{C}$ for $10 \mathrm{~min}$ can delete allergenic epitopes and increase the antioxidant capacity, anti-angiotensin enzyme activity, and antibacterial activity compared to native milk protein concentrate. According to the literature review, it may be considered that it is the first approach in the context of development of dairy-based hypoallergenic functional food by membrane- and enzyme- based technologies.

\section{Conclusions}

In the present investigation, liquid milk protein concentrate with antioxidant capacity, anti-angiotensin activity, antibacterial activity, and allergen-free was produced from ultra-heat-treated skimmed milk by combination of membrane- and enzyme- based technologies. A ceramic-made tubular nanofiltration membrane with pore size $5 \mathrm{~nm}$, placed in a cross-flow membrane house, was used for the production of liquid milk protein concentrate by reducing milk serum as a permeate. As the mean radius of casein micelle and their conjugated form with whey proteins in ultra-heat-treated skimmed milk were quite high compared to the pore size of the nanofiltration membrane, they were almost rejected by the membrane. Membrane filtration process alone cannot change the biological activities of milk proteins. Biological activities of protein derivatives, i.e., peptides offer antioxidant capacity, angiotensin converting enzyme inhibitory activity, and antibacterial activity. Therefore, milk with concentrated proteins from the retentate side of the membrane was treated with the different concentrations of trypsin, such as $0.008 \mathrm{~g} \cdot \mathrm{L}^{-1}, 0.016 \mathrm{~g} \cdot \mathrm{L}^{-1}, 0.032 \mathrm{~g} \cdot \mathrm{L}^{-1}$, and $0.064 \mathrm{~g} \cdot \mathrm{L}^{-1}$ in individual batch-mode experiments. Hydrolysis of milk protein was enzyme dose dependent because trypsin cleaves the peptide bond at the C-terminus of lysin and arginine in specific way. Antioxidant capacity, angiotensin converting enzyme inhibitory activity, and antibacterial activity of liquid milk protein concentrate were increased depending on the enzymatic hydrolysis of milk proteins. Trypsin concentration $0.032 \mathrm{~g} \cdot \mathrm{L}^{-1}$ was able to reduce allergenic epitopes at more than $99.9 \%$ in liquid milk protein concentrate.

After summarizing all experimental results, one may believe that the proposed technology may reduce the limitations of milk protein concentrate production and increase the consumption of dairy products. To the best of our knowledge, this is the first attempt to produce liquid milk protein concentrate with antioxidant capacity, angiotensin converting enzyme inhibitory activity, antibacterial activity, and hypoallergenic property by membrane filtration and enzymatic modification of proteins. In general, small-scale and medium-scale dairy plants prefer to use liquid milk protein concentrate for preparing cultured-dairy products instead of using dried milk protein concentrate for economical issue. Therefore, to implement this process in industrial scale, further systematic investigation with 
techno-economical viewpoint is a prerequisite. However, in the present investigation molecular weight of peptides derived from concentrated milk proteins were determined by SDS-PAGE; more accurate results about molecular mass distribution of peptides and their sequences may be determined by a LC-ESI-Q-TOF-MS-based bottom-up sequencing in future research. In the groundbreaking research area of food biotechnology, one may expect that the proposed research may receive attention from academic and industrial sectors.

Author Contributions: A.N. was involved in performing the experiment, evaluating the results, and writing the whole manuscript. B.A.E. and A.C. were involved in assisting with the experiments, preparing graphs, and tables. G.K. was involved in the microbiological assay. L.A., A.T., E.S., and A.K. were involved in performing the biochemical assay. Z.K. was involved in statistical analysis. K.P.-H. and G.V. were involved in cross checking results and correcting the whole manuscript. All authors have read and agreed to the published version of the manuscript.

Funding: This research received no external funding.

Acknowledgments: Authors acknowledge the support from the European Union project (grant agreement no. EFOP-3.6.3-VEKOP-16-2017-00005). A. Csighy acknowledges Doctoral School of Food Science, Szent István University, Hungary. Z. Kovacs acknowledges the support of the New National Excellence Program of the Ministry for Innovation and Technology (ÚNKP-19-4-SZIE-27) and the Bolyai János Scholarship from the Hungarian Academy of Sciences. L. Abrankó is grateful for the János Bolyai Research Scholarship from the Hungarian Academy of Sciences. This research was supported by the Higher Education Institutional Excellence Program (FEKUTSTRAT) awarded by the Ministry of Human Capacities within the framework of plant breeding and plant protection researches of Szent István University, Budapest, Hungary.

Conflicts of Interest: The authors declare no conflict of interest.

\section{References}

1. St-Onge, M.-P.; Farnworth, E.R.; Jones, P.J. Consumption of fermented and nonfermented dairy products: Effects on cholesterol concentrations and metabolism. Am. J. Clin. Nutr. 2000, 71, 674-681. [CrossRef] [PubMed]

2. Guinee, T.P.; O'Kennedy, B.T.; Kelly, P.M. Effect of Milk Protein Standardization Using Different Methods on the Composition and Yields of Cheddar Cheese. J. Dairy Sci. 2006, 89, 468-482. [CrossRef]

3. Amatayakul, T.; Sherkat, F.; Shah, N.P. Syneresis in set yogurt as affected by EPS starter cultures and levels of solids. Int. J. Dairy Technol. 2006, 59, 216-221. [CrossRef]

4. Schuck, P.; Jeantet, R.; Bhandari, B.; Chen, X.D.; Perrone, Í.T.; De Carvalho, A.F.; Fenelon, M.; Kelly, P. Recent advances in spray drying relevant to the dairy industry: A comprehensive critical review. Dry. Technol. 2016, 34, 1773-1790. [CrossRef]

5. Ur Rehman, S.; Farkye, N.Y.; Considine, T.; Schaffner, A.; Drake, M.A. Effects of Standardization of Whole Milk with Dry Milk Protein Concentrate on the Yield and Ripening of Reduced-Fat Cheddar Cheese. J. Dairy Sci. 2003, 86, 1608-1615. [CrossRef]

6. Meena, G.S.; Singh, A.K.; Panjagari, N.R.; Arora, S. Milk protein concentrates: Opportunities and challenges. J. Food Sci. Technol. 2017, 54, 3010-3024. [CrossRef]

7. Amelia, I.; Barbano, D.M. Production of an $18 \%$ protein liquid micellar casein concentrate with a long refrigerated shelf life. J. Dairy Sci. 2013, 96, 3340-3349. [CrossRef]

8. Henriques, M.H.F.; Gomes, D.M.G.S.; Pereira, C.J.D.; Gil, M.H.M. Effects of Liquid Whey Protein Concentrate on Functional and Sensorial Properties of Set Yogurts and Fresh Cheese. Food Bioprocess Technol. 2013, 6 , 952-963. [CrossRef]

9. Rosenberg, M. Current and future applications for membrane processes in the dairy industry. Trends Food Sci. Technol. 1995, 6, 12-19. [CrossRef]

10. Pouliot, Y. Membrane processes in dairy technology-From a simple idea to worldwide panacea. Int. Dairy J. 2008, 18, 735-740. [CrossRef]

11. Kumar, P.; Sharma, N.; Ranjan, R.; Kumar, S.; Bhat, Z.F.; Jeong, D.K. Perspective of Membrane Technology in Dairy Industry: A Review. Asian Australas. J. Anim. Sci. 2013, 26, 1347. [CrossRef] [PubMed]

12. Li, H.; Hsu, Y.-C.; Zhang, Z.; Dharsana, N.; Ye, Y.; Chen, V. The influence of milk components on the performance of ultrafiltration/diafiltration of concentrated skim milk. Sep. Sci. Technol. 2017, 52, 381-391. [CrossRef] 
13. Arunkumar, A.; MR, E. Milk Protein Concentration Using Negatively Charged Ultrafiltration Membranes. Foods 2018, 7, 134. [CrossRef] [PubMed]

14. Gavazzi-April, C.; Benoit, S.; Doyen, A.; Britten, M.; Pouliot, Y. Preparation of milk protein concentrates by ultrafiltration and continuous diafiltration: Effect of process design on overall efficiency. J. Dairy Sci. 2018, 101, 9670-9679. [CrossRef] [PubMed]

15. Ng, K.S.Y.; Haribabu, M.; Harvie, D.J.E.; Dunstan, D.E.; Martin, G.J.O. Mechanisms of flux decline in skim milk ultrafiltration: A review. J. Membr. Sci. 2017, 523, 144-162. [CrossRef]

16. Bacchin, P.; Aimar, P.; Field, R.W. Critical and sustainable fluxes: Theory, experiments and applications. J. Membr. Sci. 2006, 281, 42-69. [CrossRef]

17. Marshall, A.D.; Munro, P.A.; Trägårdh, G. The effect of protein fouling in microfiltration and ultrafiltration on permeate flux, protein retention and selectivity: A literature review. Desalination 1993, 91, 65-108. [CrossRef]

18. Bahnasawy, A.H.; Shenana, M.E. Flux behavior and energy consumption of ultrafiltration (UF) process of milk. Aust. J. Agric. Eng. 2010, 1, 54-65.

19. Méthot-Hains, S.; Benoit, S.; Bouchard, C.; Doyen, A.; Bazinet, L.; Pouliot, Y. Effect of transmembrane pressure control on energy efficiency during skim milk concentration by ultrafiltration at 10 and $50{ }^{\circ} \mathrm{C}$. J. Dairy Sci. 2016, 99, 8655-8664. [CrossRef]

20. Guetouache, M.; Guessas, B.; Medjekal, S. Composition and nutritional value of raw milk 2014. Bio. Sci. Pharm. Res. 2014, 2, 115-122.

21. Walsh, J.; Meyer, R.; Shah, N.; Quekett, J.; Fox, A.T. Differentiating milk allergy (IgE and non-IgE mediated) from lactose intolerance: Understanding the underlying mechanisms and presentations. Br. J. Gen. Pract. 2016, 66, e609-e611. [CrossRef] [PubMed]

22. Lifschitz, C.; Szajewska, H. Cow's milk allergy: Evidence-based diagnosis and management for the practitioner. Eur. J. Pediatrics 2015, 174, 141-150. [CrossRef] [PubMed]

23. Sicherer, S.H.; Sampson, H.A. Food allergy: Epidemiology, pathogenesis, diagnosis, and treatment. J. Allergy Clin. Immunol. 2014, 133, 291-307. [CrossRef]

24. US Food and Drug Administration. Food Allergen Labeling and Consumer Protection Act of 2004 (FALCPA). J. Acad. Nutr. Diet. 2004, 106, 1742-1744.

25. Sackesen, C.; Altintas, D.U.; Bingol, A.; Bingol, G.; Buyuktiryaki, B.; Demir, E.; Kansu, A.; Kuloglu, Z.; Tamay, Z.; Sekerel, B.E.; et al. Current Trends in Tolerance Induction in Cow's Milk Allergy: From Passive to Proactive Strategies. Front. Pediatrics 2019, 7, 372. [CrossRef]

26. Forouhi, N.G.; Krauss, R.M.; Taubes, G.; Willett, W. Dietary fat and cardiometabolic health: Evidence, controversies, and consensus for guidance. BMJ 2018, 361. [CrossRef]

27. Lordan, R.; Tsoupras, A.; Mitra, B.; Zabetakis, I. Dairy Fats and Cardiovascular Disease: Do We Really Need to be Concerned? Foods 2018, 7, 29. [CrossRef]

28. Ferreira, L.S.S.; Fernandes, C.S.; Vieira, M.N.N.; De Felice, F.G. Insulin Resistance in Alzheimer's Disease. Front. Neurosci. 2018, 12. [CrossRef]

29. Lee, H.J.; Seo, H.I.; Cha, H.Y.; Yang, Y.J.; Kwon, S.H.; Yang, S.J. Diabetes and Alzheimer's Disease: Mechanisms and Nutritional Aspects. Clin. Nutr. Res. 2018, 7, 229-240. [CrossRef]

30. Xu, Q.; Shi, J.; Yao, M.; Jiang, M.; Luo, Y. Effects of heat treatment on the antigenicity of four milk proteins in milk protein concentrates. Food Agric. Immunol. 2016, 27, 401-413. [CrossRef]

31. Villa, C.; Costa, J.; Mafra, I. Detection and Quantification of Milk Ingredients as Hidden Allergens in Meat Products by a Novel Specific Real-Time PCR Method. Biomolecules 2019, 9, 804. [CrossRef] [PubMed]

32. Villa, C.; Costa, J.; Oliveira, M.B.P.P.; Mafra, I. Bovine Milk Allergens: A Comprehensive Review. Compr. Rev. Food Sci. Food Saf. 2018, 17, 137-164. [CrossRef]

33. Bu, G.; Luo, Y.; Chen, F.; Liu, K.; Zhu, T. Milk processing as a tool to reduce cow's milk allergenicity: A mini-review. Dairy Sci. Technol. 2013, 93, 211-223. [CrossRef] [PubMed]

34. Kleber, N.; Maier, S.; Hinrichs, J. Antigenic response of bovine $\beta$-lactoglobulin influenced by ultra-high pressure treatment and temperature. Innov. Food Sci. Emerg. Technol. 2007, 8, 39-45. [CrossRef]

35. Chicón, R.; Belloque, J.; Alonso, E.; López-Fandiño, R. Immunoreactivity and digestibility of high-pressure-treated whey proteins. Int. Dairy J. 2008, 18, 367-376. [CrossRef]

36. Kleber, N.; Hinrichs, J. Antigenic response of $\beta$-lactoglobulin in thermally treated bovine skim milk and sweet whey. Milchwissenschaft 2007, 62, 121-124. 
37. Fiocchi, A.; Restani, P.; Riva, E.; Mirri, G.P.; Santini, I.; Bernardo, L.; Galli, C.L. Heat treatment modifies the allergenicity of beef and bovine serum albumin. Allergy 2008, 53, 798-802. [CrossRef]

38. Bu, G.; Luo, Y.; Zheng, Z.; Zheng, H. Effect of heat treatment on the antigenicity of bovine $\alpha$-lactalbumin and $\beta$-lactoglobulin in whey protein isolate. Food Agric. Immunol. 2009, 20, 195-206. [CrossRef]

39. Ismahan, B.D.; Hanane, K.; Omar, K.; Djamel, S. Microwave irradiation of bovine milk reduces allergic response in mouse model of food allergy. Front. Immunol. 2014, 10. [CrossRef]

40. Cheison, S.C.; Wang, Z.; Xu, S.-Y. Preparation of Whey Protein Hydrolysates Using a Single- and Two-Stage Enzymatic Membrane Reactor and Their Immunological and Antioxidant Properties: Characterization by Multivariate Data Analysis. J. Agric. Food Chem. 2007, 55, 3896-3904. [CrossRef]

41. Guadix, A.; Camacho, F.; Guadix, E.M. Production of whey protein hydrolysates with reduced allergenicity in a stable membrane reactor. J. Food Eng. 2006, 72, 398-405. [CrossRef]

42. Kobayashi, K.; Hirano, A.; Ohta, A.; Yoshida, T.; Takahashi, K.; Hattori, M. Reduced Immunogenicity of $\beta$-Lactoglobulin by Conjugation with Carboxymethyl Dextran Differing in Molecular Weight. J. Agric. Food Chem. 2001, 49, 823-831. [CrossRef]

43. Bu, G.; Lu, J.; Zheng, Z.; Luo, Y. Influence of Maillard reaction conditions on the antigenicity of bovine $\alpha$-lactalbumin using response surface methodology. J. Sci. Food Agric. 2009, 89, 2428-2434. [CrossRef]

44. Bu, G.; Luo, Y.; Lu, J.; Zhang, Y. Reduced antigenicity of $\beta$-lactoglobulin by conjugation with glucose through controlled Maillard reaction conditions. Food Agric. Immunol. 2010, 21, 143-156. [CrossRef]

45. Pahud, J.J.; Monti, J.C.; Jost, R. Allergenicity of whey protein: Its modification by tryptic in vitro hydrolysis of the protein. J. Pediatric Gastroenterol. Nutr. 1985, 4, 408-413. [CrossRef]

46. Nakamura, T.; Sado, H.; Syukunobe, Y.; Hirota, T. Antigenicity of whey protein hydrolysates prepared by combination of two proteases. Milchwissenschaft 1993, 48, 667-670.

47. Wroblewska, B.; Karamac, M.; Amarowicz, R.; Szymkiewicz, A.; Troszynska, A.; Kubicka, E. Immunoreactive properties of peptide fractions of cow whey milk proteins after enzymatic hydrolysis. Int. J. Food Sci. Technol. 2004, 39, 839-850. [CrossRef]

48. Ena, J.M.; Beresteijn, E.C.H.; Robben, A.J.P.M.; Schmidt, D.G. Whey Protein Antigenicity Reduction by Fungal Proteinases and a Pepsin/Pancreatin Combination. J. Food Sci. 1995, 60, 104-110. [CrossRef]

49. Chicón, R.; Belloque, J.; Recio, I.; López-Fandiño, R. Influence of high hydrostatic pressure on the proteolysis of $\beta$-lactoglobulin A by trypsin. J. Dairy Res. 2006, 73, 121-128. [CrossRef]

50. Bonomi, F.; Fiocchi, A.; Frøkiær, H.; Gaiaschi, A.; Iametti, S.; Poiesi, C.; Rasmussen, P.; Restani, P.; Rovere, P. Reduction of immunoreactivity of bovine $\beta$-lactoglobulin upon combined physical and proteolytic treatment. J. Dairy Res. 2003, 70, 51-59. [CrossRef]

51. Beran, M.; Klubal, R.; Molik, P.; Strohalm, J.; Urban, M.; Klaudyova, A.A.; Prajzlerova, K. Influence of high-hydrostatic pressure on tryptic and chymotryptic hydrolysis of milk proteins. High Press. Res. 2009, 29, 23-27. [CrossRef]

52. El Mecherfi, K.E.; Saidi, D.; Kheroua, O.; Boudraa, G.; Touhami, M.; Rouaud, O.; Curet, S.; Choiset, Y.; Rabesona, H.; Chobert, J.-M.; et al. Combined microwave and enzymatic treatments for $\beta$-lactoglobulin and bovine whey proteins and their effect on the IgE immunoreactivity. Eur. Food Res. Technol. 2011, 233, 859-867. [CrossRef]

53. Izquierdo, F.J.; Alli, I.; Yaylayan, V.; Gomez, R. Microwave-assisted digestion of $\beta$-lactoglobulin by pronase, $\alpha$-chymotrypsin and pepsin. Int. Dairy J. 2007, 17, 465-470. [CrossRef]

54. Izquierdo, F.J.; Peñas, E.; Baeza, M.L.; Gomez, R. Effects of combined microwave and enzymatic treatments on the hydrolysis and immunoreactivity of dairy whey proteins. Int. Dairy J. 2008, 18, 918-922. [CrossRef]

55. Yang, W.; Tu, Z.; Wang, H.; Zhang, L.; Kaltashov, I.A.; Zhao, Y.; Niu, C.; Yao, H.; Ye, W. The mechanism of reduced IgG/IgE-binding of $\beta$-lactoglobulin by pulsed electric field pretreatment combined with glycation revealed by ECD/FTICR-MS. Food Funct. 2018, 9, 417-425. [CrossRef]

56. Quintieri, L.; Monaci, L.; Baruzzi, F.; Giuffrida, M.G.; De Candia, S.; Caputo, L. Reduction of whey protein concentrate antigenicity by using a combined enzymatic digestion and ultrafiltration approach. J. Food Sci. Technol. 2017, 54, 1910-1916. [CrossRef]

57. El Mecherfi, K.E.; Curet, S.; Lupi, R.; Larré, C.; Rouaud, O.; Choiset, Y.; Rabesona, H.; Haertlé, T. Combined microwave processing and enzymatic proteolysis of bovine whey proteins: The impact on bovine $\beta$-lactoglobulin allergenicity. J. Food Sci. Technol. 2019, 56, 177-186. [CrossRef]

58. Spies, J.B. Milk Allergy. Milk Food Technol. 1973, 36, 225-231. [CrossRef] 
59. El-Agamy, E.I. The challenge of cow milk protein allergy. Small Rumin. Res. 2007, 68, 64-72. [CrossRef]

60. Kim, S.B.; Ki, K.S.; Khan, M.A.; Lee, W.S.; Lee, H.J.; Ahn, B.S.; Kim, H.S. Peptic and Tryptic Hydrolysis of Native and Heated Whey Protein to Reduce Its Antigenicity. J. Dairy Sci. 2007, 90, 4043-4050. [CrossRef]

61. Ahmad, N.; Imran, M.; Khan, M.K.; Nisa, M.U. Degree of hydrolysis and antigenicity of buffalo alpha S1 casein and its hydrolysates in children with cow milk allergy. Food Agric. Immunol. 2016, 27, 87-98. [CrossRef]

62. Abd El-Fattah, A.M.; Sakr, S.S.; El-Dieb, S.M.; Elkashef, H.A.S. Bioactive peptides with ACE-I and antioxidant activity produced from milk proteolysis. Int. J. Food Prop. 2017, 20, 3033-3042. [CrossRef]

63. Luo, Y.; Pan, K.; Zhong, Q. Physical, chemical and biochemical properties of casein hydrolyzed by three proteases: Partial characterizations. Food Chem. 2014, 155, 146-154. [CrossRef] [PubMed]

64. Bamdad, F.; Shin, S.H.; Suh, J.-W.; Nimalaratne, C.; Sunwoo, H. Anti-Inflammatory and Antioxidant Properties of Casein Hydrolysate Produced Using High Hydrostatic Pressure Combined with Proteolytic Enzymes. Molecules 2017, 22, 609. [CrossRef] [PubMed]

65. Nath, A.; Szécsi, G.; Csehi, B.; Mednyánszky, Z.; Kiskó, G.; Bányai, É.; Dernovics, M.; Koris, A. Production of Hypoallergenic Antibacterial Peptides from Defatted Soybean Meal by a Membrane Associated Bioreactor: A Bioprocess Engineering Study with Comprehensive Product Characterization. Food Technol. Biotechnol. 2017, 55, 308-324. [CrossRef] [PubMed]

66. Nath, A.; Chakraborty, S.; Bhattacharjee, C.; Chowdhury, R. Studies on the separation of proteins and lactose from casein whey by cross-flow ultrafiltration. Desalin. Water Treat. 2015, 54, 481-501. [CrossRef]

67. Nath, A.; Kailo, G.G.; Mednyánszky, Z.; Kiskó, G.; Csehi, B.; Pásztorné-Huszár, K.; Gerencsér-Berta, R.; Galambos, I.; Pozsgai, E.; Bánvölgyi, S.; et al. Antioxidant and Antibacterial Peptides from Soybean Milk through Enzymatic- and Membrane-Based Technologies. Bioengineering 2019, 7, 5. [CrossRef]

68. Nongonierma, A.B.; Paolella, S.; Mudgil, P.; Maqsood, S.; FitzGerald, R.J. Dipeptidyl peptidase IV (DPP-IV) inhibitory properties of camel milk protein hydrolysates generated with trypsin. J. Funct. Foods 2017, 34, 49-58. [CrossRef]

69. Cheison, S.C.; Schmitt, M.; Leeb, E.; Letzel, T.; Kulozik, U. Influence of temperature and degree of hydrolysis on the peptide composition of trypsin hydrolysates of $\beta$-lactoglobulin: Analysis by LC-ESI-TOF/MS. Food Chem. 2010, 121, 457-467. [CrossRef]

70. Elfagm, A.A.; Wheelock, J.V. Interaction of Bovine $\alpha$-Lactalbumin and $\beta$-Lactoglobulin during Heating. J. Dairy Sci. 1978, 61, 28-32. [CrossRef]

71. De Wit, J.; Klarenbeek, B. Effects of Various Heat Treatments on Structure and Solubility of Whey Proteins. J. Dairy Sci. 1984, 67, 2701-2710. [CrossRef]

72. Cassiani, D.M.; Yamul, D.K.; Conforti, P.A.; Pérez, V.A.; Lupano, C.E. Structure and Functionality of Whey Protein Concentrate-Based Products with Different Water Contents. Food Bioprocess Technol. 2013, 6, 217-227. [CrossRef]

73. Rauh, V.M.; Johansen, L.B.; Bakman, M.; Ipsen, R.; Paulsson, M.; Larsen, L.B.; Hammershøj, M. Protein lactosylation in UHT milk during storage measured by Liquid Chromatography-Mass Spectrometry and quantification of furosine. Int. J. Dairy Technol. 2015, 68, 486-494. [CrossRef]

74. Csehi, B.; Szerdahelyi, E.; Pásztor-Huszár, K.; Salamon, B.; Tóth, A.; Zeke, I.; Jónás, G.; Friedrich, L. Changes of protein profiles in pork and beef meat caused by high hydrostatic pressure treatment. Acta Aliment. 2016, 45, 565-571. [CrossRef]

75. Hajós, G.; Polgár, M.; Farkas, J. High-pressure effects on IgE immunoreactivity of proteins in a sausage batter. Innov. Food Sci. Emerg. Technol. 2004, 5, 443-449. [CrossRef]

76. Benzie, I.F.F.; Strain, J.J. The Ferric Reducing Ability of Plasma (FRAP) as a Measure of "Antioxidant Power": The FRAP Assay. Anal. Biochem. 1996, 239, 70-76. [CrossRef]

77. Fagyas, M.; Úri, K.; Siket, I.M.; Daragó, A.; Boczán, J.; Bányai, E.; Édes, I.; Papp, Z.; Tóth, A. New Perspectives in the Renin-Angiotensin-Aldosterone System (RAAS) I: Endogenous Angiotensin Converting Enzyme (ACE) Inhibition. PLoS ONE 2014, 9, e87843. [CrossRef]

78. Bradford, M.M. A rapid and sensitive method for the quantitation of microgram quantities of protein utilizing the principle of protein-dye binding. Anal. Biochem. 1976, 72, 248-254. [CrossRef]

79. Hussein, K.; Friedrich, L.; Kisko, G.; Ayari, E.; Nemeth, C.; Dalmadi, I. Use of allyl-isothiocyanate and carvacrol to preserve fresh chicken meat during chilling storage. Czech J. Food Sci. 2019, 37, 417-424. [CrossRef] 
80. De Wit, J.N. Nutritional and Functional Characteristics of Whey Proteins in Food Products. J. Dairy Sci. 1998, 81, 597-608. [CrossRef]

81. Penfield, M.P.; Campbell, A.M.; Penfield, M.P.; Campbell, A.M. Chapter 8-Milk and Milk Products. In Food Science and Technology, 3rd ed.; Penfield, M.P., Campbell, A.M.B.T.-E.F.S., Eds.; Academic Press: San Diego, CA, USA, 1990; pp. 162-183, ISBN 978-0-12-157920-3.

82. Relkin, P.; Mulvihill, D.M. Thermal unfolding of $\beta$-lactoglobulin, $\alpha$-lactalbumin, and bovine serum albumin. A thermodynamic approach. Crit. Rev. Food Sci. Nutr. 1996, 36, 565-601. [CrossRef] [PubMed]

83. Lee, Y.-R.; Hong, Y.-H. Electrophoretic Behaviors of $\alpha$-Lactalbumin and $\beta$-Lactoglobulin Mixtures Caused by Heat Treatment. Asian Australas. J. Anim. Sci. 2003, 16, 1041-1045. [CrossRef]

84. Manderson, G.A.; Hardman, M.J.; Creamer, L.K. Effect of Heat Treatment on the Conformation and Aggregation of $\beta$-Lactoglobulin A, B, and C. J. Agric. Food Chem. 1998, 46, 5052-5061. [CrossRef]

85. Law, A.J.R.; Horne, D.S.; Banks, J.M.; Leaver, J. Heat-induced changes in the whey proteins and caseins. Milchwissenschaft 1994, 49, 125-129.

86. Dannenberg, F.; Kessler, H.-G. Reaction Kinetics of the Denaturation of Whey Proteins in Milk. J. Food Sci. 1988, 53, 258-263. [CrossRef]

87. Dannenberg, F.; Kessler, H.G. Thermodynamic approach to kinetics of $\beta$-lactoglobulin denaturation in heated skim milk and sweet whey. Milchwissenschaft 1988, 43, 139-142.

88. Dalgleish, D.G. Denaturation and aggregation of serum proteins and caseins in heated milk. J. Agric. Food Chem. 1990, 38, 1995-1999. [CrossRef]

89. Gezimati, J.; Singh, H.; Creamer, L.K. Heat-Induced Interactions and Gelation of Mixtures of Bovine $\beta$-Lactoglobulin and Serum Albumin. J. Agric. Food Chem. 1996, 44, 804-810. [CrossRef]

90. Sawyer, W.H. Complex Between $\beta$-Lactoglobulin and k-Casein. A Review. J. Dairy Sci. 1969, 52, 1347-1355. [CrossRef]

91. Sawyer, W.H.; Coulter, S.T.; Jenness, R. Role of Sulfhydryl Groups in the Interaction of k-Casein and $\beta$-Lactoglobulin. J. Dairy Sci. 1963, 46, 564-565. [CrossRef]

92. Jang, H.; Swaisgood, H. Disulfide Bond Formation Between Thermally Denatured $\beta$-Lactoglobulin and K-Casein in Casein Micelles. J. Dairy Sci. 1990, 73, 900-904. [CrossRef]

93. Morr, C.V.; Ha, E.Y.W. Whey protein concentrates and isolates: Processing and functional properties. Crit. Rev. Food Sci. Nutr. 1993, 33, 431-476. [CrossRef] [PubMed]

94. Buchert, J.; Ercili Cura, D.; Ma, H.; Gasparetti, C.; Monogioudi, E.; Faccio, G.; Mattinen, M.; Boer, H.; Partanen, R.; Selinheimo, E.; et al. Crosslinking Food Proteins for Improved Functionality. Annu. Rev. Food Sci. Technol. 2010, 1, 113-138. [CrossRef]

95. Gerrard, J.A. Protein-protein crosslinking in food: Methods, consequences, applications. Trends Food Sci. Technol. 2002, 13, 391-399. [CrossRef]

96. Singh, H. Modification of food proteins by covalent crosslinking. Trends Food Sci. Technol. 1991, 2, $196-200$. [CrossRef]

97. Miranda, G.; Bianchi, L.; Krupova, Z.; Trossat, P.; Martin, P. An improved LC-MS method to profile molecular diversity and quantify the six main bovine milk proteins, including genetic and splicing variants as well as post-translationally modified isoforms. Food Chem. X 2020, 5, 100080. [CrossRef]

98. Singh, H. Heat stability of milk. Int. J. Dairy Technol. 2004, 57, 111-119. [CrossRef]

99. Kastrup Dalsgaard, T.; Holm Nielsen, J.; Bach Larsen, L. Proteolysis of milk proteins lactosylated in model systems. Mol. Nutr. Food Res. 2007, 51, 404-414. [CrossRef]

100. Czerwenka, C.; Maier, I.; Pittner, F.; Lindner, W. Investigation of the lactosylation of whey proteins by liquid chromatography-Mass spectrometry. J. Agric. Food Chem. 2006, 54, 8874-8882. [CrossRef]

101. Losito, I.; Carbonara, T.; Monaci, L.; Palmisano, F. Evaluation of the thermal history of bovine milk from the lactosylation of whey proteins: An investigation by liquid chromatography-Electrospray ionization mass spectrometry. Anal. Bioanal. Chem. 2007, 389, 2065-2074. [CrossRef]

102. Almaas, H.; Cases, A.-L.; Devold, T.; Holm, H.; Langsrud, T.; Aabakken, L.; Aadnoey, T.; Vegarud, G. In vitro digestion of bovine and caprine milk by human gastric and duodenal enzymes. Int. Dairy J. 2006, 16, 961-968. [CrossRef] 
103. Costa, F.F.; Vasconcelos Paiva Brito, M.A.; Moreira Furtado, M.A.; Martins, M.F.; Leal de Oliveira, M.A.; Mendonça De Castro Barra, P.; Amigo Garrido, L.; Siqueira De Oliveira Dos Santos, A. Microfluidic chip electrophoresis investigation of major milk proteins: Study of buffer effects and quantitative approaching. Anal. Methods 2014, 6, 1666-1673. [CrossRef]

104. Wróblewska, B.; Kaliszewska, A. Cow's Milk Proteins Immunoreactivity and Allergenicity in Processed Food. Czech J. Food Sci. 2012, 30, 211-219. [CrossRef]

105. Hong, Y.-H.; Creamer, L.K. Changed protein structures of bovine $\beta$-lactoglobulin B and $\alpha$-lactalbumin as a consequence of heat treatment. Int. Dairy J. 2002, 12, 345-359. [CrossRef]

106. Dunnill, P.; Green, D.W. Sulphydryl groups and the $\mathrm{N} \rightleftarrows \mathrm{R}$ conformational change in $\beta$-lactoglobulin. J. Mol. Biol. 1966, 15, 147-151. [CrossRef]

107. Havea, P.; Singh, H.; Creamer, L.K. Characterization of heat-induced aggregates of $\beta$-lactoglobulin, $\alpha$-lactalbumin and bovine serum albumin in a whey protein concentrate environment. J. Dairy Res. 2001, 68, 483-497. [CrossRef]

108. Raak, N.; Abbate, R.; Lederer, A.; Rohm, H.; Jaros, D. Size Separation Techniques for the Characterisation of Cross-Linked Casein: A Review of Methods and Their Applications. Separations 2018, 5, 14. [CrossRef]

109. Wu, Z.; Tiambeng, T.N.; Cai, W.; Chen, B.; Lin, Z.; Gregorich, Z.R.; Ge, Y. Impact of Phosphorylation on the Mass Spectrometry Quantification of Intact Phosphoproteins. Anal. Chem. 2018, 90, 4935-4939. [CrossRef]

110. Bobe, G.; Beitz, D.C.; Freeman, A.E.; Lindberg, G.L. Sample Preparation Affects Separation of Whey Proteins by Reversed-Phase High-Performance Liquid Chromatography. J. Agric. Food Chem. 1998, 46, 1321-1325. [CrossRef]

111. Cheema, M.; Mohan, M.S.; Campagna, S.R.; Jurat-Fuentes, J.L.; Harte, F.M. The association of low-molecular-weight hydrophobic compounds with native casein micelles in bovine milk. J. Dairy Sci. 2015, 98, 5155-5163. [CrossRef]

112. Assem, F.M.; Abd El-Gawad, M.A.M.; Kassem, J.M.; Abd El-Salam, M.H. Proteolysis and antioxidant activity of peptic, tryptic and chymotryptic hydrolysates of cow, buffalo, goat and camel caseins. Int. J. Dairy Technol. 2018, 71, 236-242. [CrossRef]

113. Power, O.; Jakeman, P.; FitzGerald, R.J. Antioxidative peptides: Enzymatic production, in vitro and in vivo antioxidant activity and potential applications of milk-derived antioxidative peptides. Amino Acids 2013, 44, 797-820. [CrossRef] [PubMed]

114. Manso, M.A.; López-Fandiño, R. Angiotensin I converting enzyme-inhibitory activity of bovine, ovine, and caprine kappa-casein macropeptides and their tryptic hydrolysates. J. Food Prot. 2003, 66, 1686-1692. [CrossRef]

115. Vermeirssen, V.; Van Camp, J.; Decroos, K.; Van Wijmelbeke, L.; Verstraete, W. The Impact of Fermentation and In Vitro Digestion on the Formation of Angiotensin-I-Converting Enzyme Inhibitory Activity from Pea and Whey Protein. J. Dairy Sci. 2003, 86, 429-438. [CrossRef]

116. Wang, C.; Tu, M.; Wu, D.; Chen, H.; Chen, C.; Wang, Z.; Jiang, L. Identification of an ACE-Inhibitory Peptide from Walnut Protein and Its Evaluation of the Inhibitory Mechanism. Int. J. Mol. Sci. 2018, 19, 1156. [CrossRef] [PubMed]

117. Pihlanto-Leppälä, A.; Rokka, T.; Korhonen, H. Angiotensin I converting enzyme inhibitory peptides derived from bovine milk proteins. Int. Dairy J. 1998, 8, 325-331. [CrossRef]

118. Abubakar, A.; Saito, T.; Kitazawa, H.; Kawai, Y.; Itoh, T. Structural Analysis of New Antihypertensive Peptides Derived from Cheese Whey Protein by Proteinase K Digestion. J. Dairy Sci. 1998, 81, 3131-3138. [CrossRef]

119. López-Fandiño, R.; Otte, J.; Van Camp, J. Physiological, chemical and technological aspects of milk-protein-derived peptides with antihypertensive and ACE-inhibitory activity. Int. Dairy J. 2006, 16, 1277-1293. [CrossRef]

120. Cheung, H.S.; Wang, F.L.; Ondetti, M.A.; Sabo, E.F.; Cushman, D.W. Binding of peptide substrates and inhibitors of angiotensin-converting enzyme. Importance of the $\mathrm{COOH}$-terminal dipeptide sequence. J. Biol. Chem. 1980, 255, 401-407.

121. Medeiros, V.; Rainha, N.; Paiva, L.; Lima, E.; Baptista, J. Bovine Milk Formula Based on Partial Hydrolysis of Caseins by Bromelain Enzyme: Better Digestibility and Angiotensin-Converting Enzyme-Inhibitory Properties. Int. J. Food Prop. 2014, 17, 806-817. [CrossRef] 
122. Malanovic, N.; Lohner, K. Antimicrobial Peptides Targeting Gram-Positive Bacteria. Pharmaceuticals 2016, 9, 59. [CrossRef] [PubMed]

123. Travkova, O.G.; Moehwald, H.; Brezesinski, G. The interaction of antimicrobial peptides with membranes. Adv. Colloid Interface Sci. 2017, 247, 521-532. [CrossRef] [PubMed]

124. Qian, F.; Sun, J.; Cao, D.; Tuo, Y.; Jiang, S.; Mu, G. Experimental and Modelling Study of the Denaturation of Milk Protein by Heat Treatment. Korean J. Food Sci. Anim. Resour. 2017, 37, 44. [CrossRef] [PubMed]

125. Abe, S.; Kabashima, K.; Moriyama, T.; Tokura, Y. Food-dependent anaphylaxis with serum $\operatorname{IgE}$ immunoreactive to dairy products containing high-molecular-weight proteins. J. Dermatol. Sci. 2010, 57, 137-140. [CrossRef]

126. Natale, M.; Bisson, C.; Monti, G.; Peltran, A.; Perono Garoffo, L.; Valentini, S.; Fabris, C.; Bertino, E.; Coscia, A.; Conti, A.; et al. Cow's milk allergens identification by two-dimensional immunoblotting and mass spectrometry. Mol. Nutr. Food Res. 2004, 48, 363-369. [CrossRef]

127. Meyer, P.; Petermeier, J.; Hartinger, M.; Kulozik, U. Concentration of Skim Milk by a Cascade Comprised of Ultrafiltration and Nanofiltration: Investigation of the Nanofiltration of Skim Milk Ultrafiltration Permeate. Food Bioprocess Technol. 2017, 10, 469-478. [CrossRef]

128. Mistry, V.V.; Hassan, H.N. Delactosed, High Milk Protein Powder. 1. Manufacture and Composition. J. Dairy Sci. 1991, 74, 1163-1169. [CrossRef]

129. Luo, X.; Ramchandran, L.; Vasiljevic, T. Lower ultrafiltration temperature improves membrane performance and emulsifying properties of milk protein concentrates. Dairy Sci. Technol. 2015, 95, 15-31. [CrossRef]

130. Rinaldoni, A.N.; Tarazaga, C.C.; Campderrós, M.E.; Padilla, A.P. Assessing performance of skim milk ultrafiltration by using technical parameters. J. Food Eng. 2009, 92, 226-232. [CrossRef]

131. Grandison, A.S.; Youravong, W.; Lewis, M.J. Hydrodynamic factors affecting flux and fouling during ultrafiltration of skimmed milk. Le Lait 2000, 80, 165-174. [CrossRef]

132. Meena, G.S.; Singh, A.K.; Arora, S.; Borad, S.; Sharma, R.; Gupta, V.K. Physico-chemical, functional and rheological properties of milk protein concentrate 60 as affected by disodium phosphate addition, diafiltration and homogenization. J. Food Sci. Technol. 2017, 54, 1678-1688. [CrossRef]

133. Meena, G.S.; Singh, A.K.; Gupta, V.K.; Borad, S.; Parmar, P.T. Effect of change in pH of skim milk and ultrafiltered/diafiltered retentates on milk protein concentrate (MPC70) powder properties. J. Food Sci. Technol. 2018, 55, 3526-3537. [CrossRef] [PubMed]

134. Meyer, P.; Mayer, A.; Kulozik, U. High concentration of skim milk proteins by ultrafiltration: Characterisation of a dynamic membrane system with a rotating membrane in comparison with a spiral wound membrane. Int. Dairy J. 2015, 51, 75-83. [CrossRef]

135. Samuelsson, G.; Dejmek, P.; Trägårdh, G.; Paulsson, M. Minimizing whey protein retention in cross-flow microfiltration of skim milk. Int. Dairy J. 1997, 7, 237-242. [CrossRef]

136. Pompei, C.; Resmini, P.; Peri, C. Skim Milk Protein Recovery and Purification by Ultrrafiltration Influence of Temperature on Permeation Rate and Retention. J. Food Sci. 1973, 38, 867-870. [CrossRef]

137. Meena, G.S.; Singh, A.K.; Gupta, V.K.; Borad, S.; Arora, S.; Tomar, S.K. Effect of pH adjustment, homogenization and diafiltration on physicochemical, reconstitution, functional and rheological properties of medium protein milk protein concentrates (MPC70). J. Food Sci. Technol. 2018, 55, 1376-1386. [CrossRef]

138. Meena, G.S.; Singh, A.K.; Gupta, V.K.; Borad, S.G.; Arora, S.; Tomar, S.K. Alteration in physicochemical, functional, rheological and reconstitution properties of milk protein concentrate powder by $\mathrm{pH}$, homogenization and diafiltration. J. Food Sci. Technol. 2019, 56, 1622-1630. [CrossRef]

(C) 2020 by the authors. Licensee MDPI, Basel, Switzerland. This article is an open access article distributed under the terms and conditions of the Creative Commons Attribution (CC BY) license (http://creativecommons.org/licenses/by/4.0/). 